\title{
The Role of Hostile Stakes in German Corporate Governance ${ }^{\dagger *}$
}

\author{
Tim Jenkinson \\ Economics Department \\ Oxford University \\ and $C E P R$
}

\author{
Alexander Ljungqvist \\ Said Business School \\ Oxford University \\ and $C E P R$
}

\begin{abstract}
This paper uses clinical evidence to show how the German system of corporate control and governance is both more active and more hostile than has previously been suggested. It provides a complete breakdown of ownership and takeover defence patterns in German listed companies and finds highly fragmented (but not dispersed) ownership in non-majority controlled firms. We document how the accumulation of hostile stakes can be used to gain control of target companies given these ownership patterns. The paper also suggests an important role for banks in helping predators accumulate, and avoid the disclosure of, large stakes.
\end{abstract}

Key words: corporate governance, block trades, takeovers, banks, Germany

JEL classification: G32

Draft: 17 August 1999

\footnotetext{
${ }^{\dagger}$ The contact details of the authors are: Tim Jenkinson, Keble College, Oxford OX1 3PG, UK. Tel: +44 1865 272766 or e-mail tim.jenkinson @ keble.ox.ac.uk; Alexander Ljungqvist, Merton College, Oxford OX1 4JD, UK. Tel: +44 1865276343 or e-mail econapl@ermine.ox.ac.uk.

* The paper has benefited from helpful discussions at Oxford Business School, Stockholm School of Economics, Lund University, Humboldt-University Berlin, London Business School, Birkbeck College, the $1^{\text {st }}$ European Corporate Governance Network conference in Milan, the 1997 European Finance Association Meeting in Vienna, and the 1997 TMR Network Conference in Florence. We are grateful to Patrick Bolton, Ernst-Ludwig von Thadden, Ekkehart Boehmer, Colin Mayer, Mike Burkart, Luc Reenebog, and Dr. Ruppelt (head of the policy unit of Germany's Federal Cartel Office) for useful comments and to Dirk Schiereck for generously making the accounting data available. Any views expressed herein are ours alone. Finally we thank an anonymous referee for particularly useful comments and suggestions. Remaining errors are the sole responsibility of the authors.
} 
There is a widespread belief that the German system of corporate governance exhibits a very low level of hostility. In the stereotypical view of German finance, hostile tender offers are virtually unheard of, with banks (rather than markets) assumed to play an important role in both the financing and control of German corporations. ${ }^{1}$ This paper challenges some important elements of this view. It is certainly true that hostile tender offers play almost no role in disciplining incumbent management. ${ }^{2}$ However, we suggest that there is a much greater incidence of outsiders accumulating hostile stakes or blocks in an attempt to gain control. Hostile stakes are often built by coalitions of large investors who share a dissatisfaction with the incumbent management, or who have other motives for seeking control. One particularly important such motive may be the expropriation of minority shareholders. The dynamics of hostile stake building are complex and difficult to observe in many cases it is not simply possible to look at a share register and infer who is exerting control over the company. This opaqueness derives from the low level of transparency of share stakes and weak regulation of parties acting in concert. Our paper seeks to overcome this opacity by taking a "clinical", or case study, approach, looking in detail at the dynamics of stake accumulation, and the control battles that ensued.

This approach is both a strength and weakness of the paper. We identify 17 cases of hostile stakebuilding over an eight-year period. This is clearly not a large number in absolute terms, nor relative to the total number of listed companies in Germany (fewer than 600 at the time). However, one should not jump to conclusions too quickly. In common with a number of other countries in Europe (excluding the UK) ownership concentration is very high in Germany. ${ }^{3}$ In Section II we look in detail at the ownership structure, and takeover defences, of all German listed companies and find that as few as 64 German companies may be vulnerable to hostile attack. The resulting 3-4\% per

\footnotetext{
${ }^{1}$ The following illustrate this conventional wisdom: Carney (1997, p. 78), “...no market for corporate control exists in Germany to cure even the most extreme monitoring problems.” Grundfest (1990, p. 105), “....in both Germany and Japan, corporate investors and intermediaries are able to reach deep into the inner workings of portfolio companies to effect fundamental management change. They do so without the need for a hostile takeover or proxy contest." Allen and Gale (1994, p. 9): "Banks are heavily involved in the control of industry and form long term relationships with firms. There is little publicly available information about firms and there is no active market for corporate control.” Franks and Mayer (1990, p. 208) “... banks protect firms from interference from external parties, in particular from hostile takeovers."

${ }^{2}$ Krupp's recent (ultimately unsuccessful) bid for rival steel producer Thyssen was possibly Germany's firstever truly Anglo-US tender offer: being open to all shareholders and offering a 25.5\% premium.

${ }^{3}$ See Becht and Barca, European Corporate Governance Network, OUP 1999.
} 
annum incidence of hostile stake-building is surprisingly similar to the incidence of hostile tender offers in, for example, the UK. ${ }^{4}$

However, whilst we argue that this incidence is economically significant, and has not previously been identified, the low absolute number of cases precludes econometric testing of formal hypotheses. On the other hand, we are able through the clinical approach to analyse in considerable detail the behaviour of the various parties involved in the control contest. For example, we analyse the behaviour of banks in such battles and find their role to be much more complex than has previously been documented. Far from protecting incumbent management, German banks have, on a number of occasions, been actively involved in bringing about hostile changes of control by facilitating stake building. We show how banks can assist predator companies in the accumulation of hostile stakes, and how beneficial ownership can be obscured. We also consider how the regulatory environment allows such stake accumulation to occur and whether recent important changes—such as the introduction of Germany's first Takeover Code-will influence the way that corporate control is exercised in the future.

The contributions of this paper are, therefore, empirical. The findings are relevant to a number of different areas of research. First, there is a rich literature, mainly focused on US companies and markets, which investigates the links between ownership structure and corporate performance. Most of this literature takes as its starting point the Berle-Means (1932) thesis that dispersed ownership leads to an agency conflict between (weak) owners and (strong) managers. Blocks in this context are typically thought to perform one of two roles: a toehold prior to a hostile takeover (Shleifer and Vishny 1986, Bulow, Huang and Klemperer 1996) or a way to mitigate the free-rider problem in monitoring management (Butz 1994, Mørck, Shleifer and Vishny 1989). The second of these roles has recently attracted a lot of attention. One strand of the literature looks at acquisitions of 5\% or more in the US, that is, the emergence of new blocks. These 'partial acquisitions' are typically greeted with positive share price responses both at the target and the buyer (see Mikkelson and Ruback 1985 for public 13-D acquisitions, Wruck 1989 for private placements), indicating that increases in ownership concentration are value-increasing. Moreover, consistent with the BerleMeans thesis, targets tend to have performed poorly prior to the partial acquisition (Choi 1991, Bethel et al. 1998) and be more diversified (Bethel et al.), whilst subsequent target firm operating

\footnotetext{
${ }^{4}$ The incidence of hostile takeovers is quite variable over time, but Jenkinson and Mayer (1994) report an average of 40 hostile bids per annum in the UK over the period 1984-89. Taking the number of potential targets as around 1,500 (excluding investment trusts) this would result in an incidence of under $3 \%$ per annum in the UK.
} 
and financial behaviour is positively affected (Spencer et al. 1998) and CEO turnover increases substantially (Bethel et al.). Finally, new blocks are more likely to emerge the lower prior ownership concentration (Bethel et al.).

A second, and related, literature focuses on existing blocks. Perhaps surprisingly, significant share blocks are common even in the US, where corporate ownership is typically more dispersed than in Germany and other continental European countries (Barclay and Holderness 1989). ${ }^{5}$ Trading in such blocks is about twice as frequent as hostile tender offers (Barclay and Holderness 1991), and typically takes place at a premium to the post-trade market price (Barclay and Holderness 1989). Since trading of existing blocks leaves ownership concentration unchanged, Barclay and Holderness (1989) suggest the block premium is consistent with private benefits of control rather than valueincreasing monitoring, though the two are not mutually exclusive: block trades are followed by an increase in CEO turnover, of a magnitude usually only seen in hostile tender offers (Barclay and Holderness 1991), and are associated with subsequent business restructuring (Denis and Serrano 1996). A look at the treatment of minority shareholders when block trades are followed by tender offers suggests that the block premium is not entirely due to private benefits: minorities are typically bought out at a premium to the block price, despite the absence of any legal compulsion (Barclay and Holderness 1991, 1992). In contrast, in Germany minorities are vulnerable to expropriation by majority owners: there is little legal requirement to buy out minority stakes, and when offers to minority shareholders are made they are typically at a large discount to the price paid by the controlling shareholder.

There are some important differences between the block trades discussed in the US literature and our cases. First, US Securities and Exchange Commission (SEC) regulations have tended to result in block trades being negotiated and publicised rather than covert. Second, partial acquisitions or trades of existing blocks take place against the background of an ownership structure which is significantly more dispersed in the US than in Germany, particularly for large firms. ${ }^{6}$ Therefore, the economically significant block size is likely different in the US and Germany, and should depend on the concentration and composition of the remaining ownership structure. Third, three-quarters of the US cases involve a simple sale of one existing block (Barclay and Holderness 1991), whilst our paper documents a much richer dynamic of blocks being built from open-market purchases, acquired from existing blockholders, and combined with other blocks. In that sense, we look at block-building,

\footnotetext{
${ }^{5}$ They quote figures from a 1984 survey by the SEC that around $20 \%$ of NYSE and AMEX companies have at least one outside shareholder owning more than $10 \%$ of the common stock.

${ }^{6}$ It should be noted that many small to medium sized firms in the US have concentrated shareholding structures.
} 
rather than block transfers. There has, to date, been little analysis of block accumulation tactics, in the US or elsewhere. ${ }^{7}$

Finally, our paper is also related to the literature on optimal takeover regulation, since we focus particularly on the ability to build hostile stakes without the knowledge of other market participants—-something that the existing block literature assumes away. For example, as Burkart (1996) notes, it is critical whether stake building, and hostile intentions, can be obscured because as soon as such a strategy becomes transparent free-riding (along the lines suggested by Grossman and Hart 1980) is likely to result. Loose disclosure and acting-in-concert regulation will provide the opportunity for hostile control changes to be effected via stake building and for such behaviour to be profitable. Such loose regulation exists in a number of continental European countries including Germany. Hence, the behaviour that we focus on in this paper is, in a sense, quite predictable, although no previous paper has, to our knowledge, provided systematic evidence on the importance of hostile acquisitions in Germany via stake building. Our paper complements that of Franks and Mayer (1995), who consider the importance of share stakes in Germany. They document a large incidence of stake changes and suggest that such changes are the most significant influence on the turnover of supervisory board members. However, Franks and Mayer consider the incidence and observed response to sales of share stakes in general, without distinguishing between the nature of these sales. In contrast we focus exclusively on hostile stake building, in particular on those cases where transactions are part of a strategy aimed at seizing control.

The remainder of the paper is organised as follows. In Section II we analyse ownership patterns in Germany and outline our research methodology and our data sources. Section III presents evidence on hostile stake accumulation for a number of recent cases, detailed chronologies of which are provided in an appendix. Section IV concludes by discussing a number of policy issues regarding corporate governance that are raised by the case studies.

\footnotetext{
${ }^{7}$ There has, however, been some interesting analysis of optimal ownership structure in the presence of blockholders (e.g. Bolton and von Thadden 1998, Zwiebel 1995). Zwiebel assumes there are private benefits of control that can be divided and shared amongst blockholders who form controlling coalitions. Zwiebel suggests that the existence of a large blockholder will tend to discourage small blockholders, who would then find it more difficult to form controlling coalitions. Hence, large blockholders tend to 'create their own space'. In contrast, our paper documents the existence of multiple competing large blockholders who are engaged in trades (often of a clandestine nature). The apparent motivation for block building is not Zwiebel's pursuit of a share in the (divisible) private benefits of control, but to effect a control change via the accumulation of a majority or controlling stake.
} 
II Data and Methodology

\section{II.1 Ownership structure in Germany}

Ownership of German companies is highly concentrated. Table 1 gives a complete breakdown of the ownership structure of all listed German firms in September 1991 by the size of the largest disclosed block, or pooled block where a pooling contract exists. ${ }^{8}$

There are five economically significant block sizes as defined by the rights of minorities and the discretionary powers of the dominant blockholders. A block of $90 \%$ or more severely restricts the residual rights of minority shareholders, who for instance can no longer make the management or supervisory boards liable for detrimental decisions; above $95 \%$, the controlling party can compulsorily acquire the minorities' shares. A block of 75\% (super-majority) or more gives the controlling party complete discretion in matters of supervisory board elections and profit-transfer and/or control agreements (without any requirement to buy out minorities) which tend to give rise to minority dilution opportunities. A block of $50 \%$ or more gives management control of the company, but is subject to limits on the controlling party's discretion due to the existence of a blocking $25 \%+$ minority. A block of $25 \%$ or more gives veto powers on corporate charter amendments, supervisory board changes, and profit-transfer and control agreements. In the absence of other large shareholders, a 25\% stake can provide substantial influence given an average presence of no more than 57\% of votes at AGMs (Baums and Fraune 1994). Finally, a block of less than 25\% gives relatively little minority protection.

As can be seen from Panel A of Table 1, 72\% of all listed companies have a majority owner: $23.1 \%$ have blocks in excess of $90 \%$ of capital (or votes, if different), $18.4 \%$ are super-majority controlled, and $30.5 \%$ have a simple-majority owner. Therefore, only $28 \%$ of companies-141 firms-are not at least majority-controlled by one blockholder. Panels B and C take a closer look at these firms. 86 of these have one or more blocking minority stakes (Panel B), where of course two or three such stakes would have amounted to combined majority or super-majority control had the various blockholders pooled their votes (which to our knowledge they had not). The remaining 55 firms, in Panel C, have no stakes in excess of $25 \%$. Thirty-seven of these have one or more disclosed non-blocking stakes, while 18 firms are classified as widely held because no stakes were disclosed at all (though Baums

\footnotetext{
${ }^{8}$ Pooling contracts are agreements between blockholders that oblige them to pool their votes. They have no special legal standing, and are typically renewable every 4-5 years.
} 
and Fraune 1994 claim that banks, despite owning only an average of 13\% of widely-held firms' equity, control more than $80 \%$ of votes via proxies).

From the point of view of corporate governance the firms in Panels B and C are very interesting. In the absence of a majority owner, there are three alternatives for how these companies are controlled. They may either be (i) run by a coalition of non-pooling blockholders, or (ii) be controlled by the dominant blockholder with the connivance of the remaining blockholders, or (iii) run by management without much shareholder influence at all, in a way reminiscent of widely held firms in the US or the UK. Given the presence of sizeable and often multiple blocks, ownership in these firms is certainly not dispersed, but rather fragmented. This, we would argue, increases the scope for hostile stake building, especially where blockholders are in disagreement over corporate policy or where blocks are up for sale.

Table 2 lists the frequency of four types of takeover defences amongst the population of all German listed companies in September 1991: instances where only non-voting preference shares are publicly traded; voting right restrictions which cap the number of votes any individual shareholder can cast; limitations on the transferability of shares (which give the target's board the option not to register the shares in the new shareholder's name, thus effectively disenfranchising the stake); and departures from the principle of one-share-one vote, as when certain classes of shares (usually held by friendly parties and not traded) have greater voting power at all times or under certain circumstances (for instance, for board elections). Not surprisingly, few of the 402 majoritycontrolled firms have takeover defences: $8.2 \%$ list only non-voting shares, $3.5 \%$ restrict the transferability of stock, and $4.7 \%$ have stock with differential voting rights (Panel A). Limits on transferability and differential voting rights are the main takeover defences amongst the 86 firms without majority owners but with one or more blocking-minorities (Panel B). However, 79\% of these 86 firms have no formal takeover defences. It is amongst the firms without blocking-minority stakes that takeover defences are most common. $42 \%$ of these 55 firms have defensive shares structures, with voting right restrictions being the most popular (Panel C).

How many of the 141 non-majority controlled firms in Panels B and C could potentially become targets of hostile stake building? Clearly not all of them: firms with three blocking-minority shareholders would be relatively hard to buy into, if only because each blockholder, being pivotal, would demand a control premium. To answer the question we propose four possible stake building strategies; see Table 3. First, a hostile bidder could attempt to build stakes in firms that have a free float of $50 \%$ or more, without buying any existing blocks. The companies which potentially fall into this category are widely held firms; companies with one blocking-minority stake; and firms with 
one or more non-blocking minority stakes. Checking for the presence of additional disclosed stakes and computing free float, we find 79 companies with a free float of $50 \%$ or more. ${ }^{9}$ Second, a bidder could take over a company by buying one or more or all existing non-blocking stakes; there were seven firms potentially at risk from this strategy. A third takeover strategy is to buy out one existing blocking-minority stake and to make up the difference to $50 \%$ via open-market purchases. Thirty firms had one or two blocking minority stakes and enough free float for this strategy potentially to allow a majority takeover. The final strategy involves a bidder buying out two existing blocking minority stakes, for instance in companies which have two or three such stakes and too little free float to make any of the other strategies viable. Therefore, of the 141 non-majority controlled, some are much more vulnerable to hostile stake building than others. In practice the first two strategies look much more feasible than the last two, suggesting the potential takeover targets might number around 86 , which represents just $15.4 \%$ of the total number of listed German firms.

If the defensive features summarised in Table 2 are effective, some of these 86 firms are unlikely to be taken over. Table 3 takes this into account by looking in detail at the nature of any takeover defences. Two companies, for instance, listed only non-voting preference shares, making them virtually immune to hostile stake-building. ${ }^{10}$ A further 20 had voting right restrictions, though we will argue later that the empirical effectiveness crucially depends on the level of the cap. Of the eleven companies with limited transferability, eight restricted transferability sufficiently to make a bidder's life difficult. Finally, of the 21 companies that had multiple classes of stock, one had sufficiently privileged stock to block hostile approaches. Depending on the effectiveness of each of these takeover barriers, the number of firms at risk from hostile stake building could fall to 110 (if all takeover strategies are considered) or as low as 64 - just $11 \%$ of all German listed firms - if only the first two strategies are considered realistic.

\footnotetext{
${ }^{9}$ This is the maximum number of firms with free float of $50 \%+$. Where there are undisclosed stakes, true free float may be less than the level we calculated.

${ }^{10}$ Non-voting shares need not always be an effective takeover barrier, as the experience of computer manufacturer Nixdorf illustrates. Nixdorf became the target of takeover rumours when one family (voting) shareholder was alleged to be looking to sell out. The reason why Nixdorf's CEO, Klaus Luft, took these rumours seriously enough to declare his opposition is a German corporate law stipulation that preference shares become enfranchised if a company passes the preferred dividend in two consecutive years-a condition which in the Nixdorf case was met. As soon as Luft resigned from the board (without giving any reasons) Siemens AG took over control by buying $51 \%$ of the voting shares from Deutsche Bank, the family and a charitable trust in a move apparently masterminded by Deutsche Bank. (As we cannot attribute hostile intentions to Siemens, we do not include this case amongst our 17.)
} 
The cases were identified using the Financial Times Mergers \& Acquisitions (FTMA) database. FTMA contains structured templated information on changes in ownership structure of European firms, covering (i) listed and unlisted firms; (ii) takeover bids and stake purchases; and (iii) transactions which are completed as well as those merely rumoured or still under negotiation. All 'forms' compiled by FTMA between January 1988 and December 1996 were obtained for transactions involving German companies as targets. This yielded 2,511 forms, some of which pertain to the same firm at different points in time, or to different bidders for the same firm at the same point in time. Two types of filters were used to manage this very large amount of raw data. 'Negative' filters were used to eliminate, without further investigation, FTMA-reported transactions with a low likelihood of being motivated by 'hostility'. These negative filters were

1. cases of apparent initiation of cross-shareholdings

2. "participation in capital increases via subscription" (which presumably are agreed between buyer and target, and thus not hostile)

3. unlisted companies other than those captured using a positive filter (see below)

4. complete or partial disposals of divisions or other operating units

5. privatisations by the Treuhandanstalt

Second, we used positive filters designed to identify cases with a high probability of being motivated by hostility, and devoted more time to these cases:

1. firms known to be potential takeover targets using our knowledge of their ownership structure discussed above (no majority owner, no pooled majority etc.)

2. multiple filings over time for the same firm

3. cases where FTMA reported transactions by 'undisclosed bidders'

For firms not eliminated by the negative filters, all electronically available news story headlines were read, and where appropriate the story itself, ${ }^{11}$ around the year indicated in FTMA to establish the nature of transaction: friendly, negotiated, don't know, openly hostile etc. At this stage a $6^{\text {th }}$ negative filter was used to exclude companies in financial distress as the change in ownership

\footnotetext{
${ }^{11}$ Electronically available news sources are: Reuters Textline, German and international newspapers, and newswires such as Press Association.
} 
structure presumably reflects rescue operations. Most effort was spent reading about transactions which passed the positive filters.

In common with existing research in the area of hostile takeovers, we do not have a precise definition of hostility. Instead, we look for such 'telltale signs' as public resistance by target management to block-building, for instance taking the form of verbal exchanges or actions designed to ward off further block-building (e.g. discouraging further stake sales) or reduce the new blockholder's influence (e.g. imposition of voting restrictions). Clearly, this unavoidably biases our sample identification since we must rely on reportable and reported reactions by target management. Where disputes take place, and stay, behind closed doors we are unable to establish the blockbuilders's intent and the target's reaction. Whilst this is unavoidable, a potentially more serious concern is Comment and Schwert's (1997) argument that using press coverage to distinguish between hostile and friendly tender offers may be misleading. Comment and Schwert find little economic difference between deals conventionally classified as friendly and hostile, and suggest that both management resistance and publication thereof are strategic bargaining ploys to improve the bid terms for target shareholders. Whilst this point is pertinent to situations where block-building is followed by tender offers (which affect target shareholders), very few of our cases involve subsequent tender offers (and those that do offer minority shareholders very poor terms).

On the basis of the news stories, 17 prima facie hostile cases were identified. We make no claims as to the comprehensiveness of our search strategy: our filters may well have filtered out hostile cases, particularly amongst unlisted firms. The filters were necessary, however, given the otherwise unmanageably large number of FTMA filings, each of which would have required a news search to establish the background.

All news stories before and after the FTMA date were then read line by line for the 17 cases. In some instances, this involved reading more than 1,000 articles (e.g., 1,283 articles on the Continental case). From these readings, we established the players, the sequence of events, information on ownership changes and prices paid (where available), the bidder's motivation, the target's response, the outcome etc. We augmented the news information with security price data (from Datastream) where we had information on dates (e.g., date of block purchase) and with ownership data from the standard German sources: Hoppenstedt's Saling stock market yearbook; Commerzbank's Wer gehört $z u$ wem? tri-annual register of corporate ownership; and the electronic Amadeus database which uses ownership files compiled by Creditreform, a credit reference agency.

We refrain from performing an event study on our cases for three main reasons. First, in contrast to 
the US or the UK, where event dates are easy to identify from SEC or stock exchange filings, it is extremely difficult to identify the dates of German block trades: the notification requirement is to the target company in the first instance. Second, the way blocks are acquired is often, and deliberately, covert, even where formal notification would in principle be required. Finally, block trades often receive press coverage only once further buying activity or target responses add up to a pattern, resulting in substantial reporting delays.

\section{The case studies}

The seventeen cases of hostile stake building provide an insight into the way corporate governance is exercised in Germany. Brief summaries of each individual case are provided in the appendix. In this section we first describe the sample companies in terms of firm characteristics, shareholder structure, and defences in place. We then turn to the various strategies employed by hostile stakebuilders, including the formation of coalitions, the role of banks and ways to avoid disclosure. We next consider the defensive actions taken by targets, including voting restrictions, denial of board representation and the use of defensive coalitions and white knights. Finally, we discuss the outcomes of the different types of control battle that are observed.

\section{III.1 Company characteristics}

Table 4 lists the 17 targets and their respective suitors. The control contests were initiated between 1987 (Axel Springer Verlag) and 1994 (Kolbenschmidt) though due to the often covert nature of stake-building precise dating is difficult. The targets are invariably from 'traditional' industries, ranging from construction (Philipp Holzmann and Dywidag) to insurance (AMB and DBV). One of the most noticeable characteristics of the case studies is that the stake-builders mostly operate in the same industry as their targets. Indeed, many cases are reminiscent of Jensen's (1993) over-capacity argument, for instance the two construction cases, the Krupp-Hoesch steel case, or any of the car industry cases. In only two instances are the control contests of a conglomerate nature. This strong horizontal (and vertical) bias results in the Cartel Office being involved in a relatively high proportion of the cases. Another striking feature of the stake-builders is their nationality: nine cases involved non-German stake-builders, including most of the earliest cases. This is consistent with 'outsiders' undermining the prevailing 'governance consensus'. It is also noteworthy that most of the stake-builders are companies, not individuals as documented in the US by Holderness and Sheehan (1985) and Bethel et al. (1998). 
The targets are mostly large companies, with nominal sales averaging DEM3.6 billion in the three years prior to the control contests (see Table 5). The smallest target (BIFAB) had annual sales of DEM44 million, and the largest target DEM13.2 billion. All but four of the targets had experienced positive sales growth in the three years leading up to the control contests, with double-digit growth rates in five cases. The earnings dynamic is more mixed, with three firms moving into losses over the three years pre-contest, two firms experiencing negative earnings growth, and the remaining twelve seeing sometimes quite substantial increases in earnings. In the year their control contests began, four firms were loss-making and six firms earned less than an eight per cent return on equity. The remaining seven, however, would appear to be performing healthily, with ROEs ranging from 10 to 22 per cent.

In line with our discussion in Section II.1, target companies typically have fragmented ownership in the run-up to their control contests (see Table 5). All but three targets would have been placed in Panel B or C of Tables 1 and $2 .{ }^{12}$ To generalise, the typical firm has one $25 \%+$ blockholder, several smaller stakes, and well below 50\% free float. The three exceptions are SEN, Wünsche and Bopp \& Reuther. SEN had a $50.01 \%$ owner and still became the target of a control contest. Wünsche was majority-controlled by two brothers who later fell out. Bopp \& Reuther, the only non-listed target in our sample, was controlled by a large number of family shareholders and one outside $25 \%+$ blockholder who originally pooled their votes.

Eight of the 17 targets had some form of takeover defence in place. Four (Asko, Continental, Hoesch and Feldmühle Nobel) had caps on voting rights, another three (the two insurers AMB and DBV, as well as Axel Springer Verlag) limited the transferability of shares, and one (Th. Goldschmidt) had differential voting rights. None of the targets listed only non-voting shares. In summary, the existence of takeover defences does not necessarily deter unwanted stake-building, though whether stake-building can be effective in such circumstances remains to be explored below.

\section{III.2 Stake accumulation tactics}

Hostile stakes can be formed either via open market purchases or by purchasing blocks from existing shareholders. As Table 6 shows, stakes are often built partially through open market purchases, but the limited secondary market liquidity that we documented in Section II typically precludes a controlling stake being accumulated without also buying (or forming coalitions with) existing 
blocks. This frequently relies on the breakdown of existing coalitions of blockholders. On a number of occasions this is what we observe. Blockholders often enter into 'pooling agreements' with each other to establish effective joint control of the company. However, such agreements are time-limited and are occasionally violated (such as in the case of Bopp \& Reuther). More often, the entry of a hostile stake-builder results in at least one member of the original pooling agreement allowing the agreement to lapse and selling their stake to the predator (such as in the cases of BIFAB and Goldschmidt). As we shall discuss below, banks often play an important role in both arranging such offensive coalitions and, significantly, helping predators build rival controlling stakes. Two particularly relevant considerations are, first, the rules governing disclosure of stakes and, second, given the horizontal nature of many of these takeovers, the threshold beyond which Cartel Office approval is required.

Disclosure problems are of particular concern since most German companies—unlike British or American ones-issue bearer shares, which make it hard to know who the shareholders are. During the period of our investigation, company law required only holdings in excess of $25 \%$ and $50 \%$ to be revealed. This contrasts with the 5\% threshold in the US (Regulation 13-D) and the 3\% threshold in the UK. The ability of a predator to build a stake without other market participants realising is important as it reduces the likelihood of other shareholders eliminating potential takeover gains by free-riding, ${ }^{13}$ and it prevents the potential target from initiating some form of anti-takeover protection such as limiting the votes that can be cast by any individual shareholder. Germany's disclosure rules have been progressively tightened in recent years, ${ }^{14}$ but it is unclear whether this in itself limits the ability to build a secret stake: banks or other friendly parties can help companies to build large stakes by combining a number of smaller stakes that individually do not have to be disclosed.

Our case studies show how weak, in practice, the disclosure rules are in Germany. For example, by splitting up his 38\% stake between himself and some of his companies and two children, Walter avoided revealing his ownership interest in Dywidag. In the Feldmühle Nobel case, the Flick brothers were able to assemble a secret $40 \%$ stake via open market purchases and undisclosed

\footnotetext{
${ }^{12}$ Note that Tables 1-3 provide a snapshot in time (1991) of Germany’s population of listed firms, whilst our cases span a eight-year period.

${ }^{13}$ As suggested, for example, by Shleifer and Vishny (1986). However, incentives for minorities to free-ride in Germany are likely to be small relative to the fears of expropriation, as we will document in Section III.4.

${ }^{14}$ The new securities trading law has introduced two lower reporting thresholds of $5 \%$ and $10 \%$. In addition, the Berlin Supreme Court ruled in 1991 that if asked at their AGMs, companies have a duty to disclose shareholdings of (i) $10 \%$ or more or (ii) a minimum market value of DM100m. The market value threshold means that share stakes of less than $1 \%$ in DAX-30 companies are declarable.
} 
agreements with institutional blockholders; indeed, having sold this stake to Veba, the Flick brothers secretively assembled a second stake which they used to extract further surplus from Veba. Effective stakes can also be hidden by the use of option contracts, such as in the Axel Springer Verlag case, where the predator had a disclosed stake of $10 \%$ but an undisclosed option on a further $16 \%$.

The second relevant threshold is that stakes in excess of $24.9 \%$ must be reported to the Cartel Office, whose permission is required before they are increased. Furthermore, a 25\% stake will often give the holder considerable power as a blocking minority, preventing a majority owner from diluting minorities or executing significant changes in corporate strategy. However, even the Cartel Office rules can be stretched. For example, in the Hochtief case, Commerzbank enabled its client to acquire an effective stake in excess of the $24.9 \%$ threshold by purchasing an additional block and granting a call option on it to Hochtief. Commerzbank was paid an undisclosed fee to finance the cost of carry; hence all the economic risks were borne by Hochtief who, in all but title, thus 'owned' the stake. ${ }^{15}$

Monopolies Commission reports have highlighted a number of other such cases. A particularly interesting one is the 1985 takeover of Deutsche SB-Kauf AG by Asko, a rival retailer. Acting in concert with three banks, Asko avoided a Cartel Office investigation by arranging for all parties to hold no more than $24.9 \%$ each, thus accumulating a stake of $99.6 \%$ ! The critical issue is clearly the regulation of parties acting in concert, which historically has been very weak in Germany. Such matters are likely to come under review by the German courts in the wake of the case brought by the Cartel Office in the Hochtief-Holzmann bid. However, whilst there may be some tightening of the rule regarding breaching the Cartel Office's $24.9 \%$ threshold, it seems less likely that regulations regarding the disclosure of beneficial ownership or, more crucially, effective control, will be changed sufficiently to remove the ability to build secret stakes significantly in excess of the formal disclosure limits. Note also that since no notification is required under any law for stake changes between $25 \%$ and $49.9 \%$, a block-builder could clandestinely build a near-controlling stake.

Turning to the source of the stakes and the role of coalitions, the case studies reveal a number of interesting features. First, in contrast to the theoretical literature (such as Zwiebel 1995) there are

\footnotetext{
${ }^{15}$ Hochtief later went a step further and signed a purchase agreement for the stake with Commerzbank, effectively raising its holding in Holzmann to $35.15 \%$. The agreement and exchange of title and consideration were contingent on Hochtief winning its appeal against the Cartel Office's ruling that it should not be allowed to increase its stake above $20 \%$. This ruling prevented Hochtief voting any excess shares pending regulatory approval, but the purchase agreement bound Commerzbank 'not to act against Hochtief's interests', a clause which would almost certainly tie Commerzbank's hands at Holzmann's AGM. When these transactions came to light, the Cartel Office started an investigation into the legality of Hochtief's dealings with Commerzbank and another bank (BfG), threatening the three companies' managers with fines of up to DM1m each.
} 
usually multiple large blockholders in our cases. This greatly increases the complexity of the game for each individual blockholder. In particular, each blockholder will fear not being part of a controlling coalition when a hostile stake-builder emerges, given the high risk of being diluted in Germany. It is not altogether surprising, therefore, that in a large number of cases existing pooling agreements break down in the face of a hostile stake-builder. For example, in the Goldschmidt case the family shareholders had a pooling agreement with Allianz which gave the coalition majority control. When VIAG emerged as a stake-builder, Allianz let its pooling contract expire and sold out to VIAG, who thereby gained control.

Second, as Table 6 shows, banks held significant stakes in a number of the cases, and often sided with the predator (either through sale or pooling). In some cases the bank stakes appear to have been long-held, although there are also examples where investment banks essentially build stakes in partnership with a predator, and appear to play a pivotal role in brokering a controlling coalition. Perhaps the most interesting example is the Hoesch takeover, where three banks held significant stakes: Deutsche Bank (Hoesch's house bank); WestLB (Krupp's—-the stake-builder's—house bank) and Credit Suisse (who were acting for Krupp). An initial 24.9\% stake was secretly accumulated by Credit Suisse on behalf of Krupp. Later in the battle, Credit Suisse accumulated a further $20 \%$ stake, which they pledged in support of Krupp. Whilst WestLB did not declare its $12 \%$ stake in support of Krupp during the battle (to avoid voting restrictions) it later worked with Krupp to have voting restrictions removed and seal the takeover. Interestingly, Krupp also enjoyed the support of Deutsche Bank, which was estimated to control around $12 \%$ of the votes (partly via proxies) ${ }^{16}$.

\section{III.3 Defensive actions}

While German firms are prevented by law from using such popular Anglo-American defence tactics as share buy-backs, issuing shares with multiple voting rights, poison pills or recapitalisations targeted at white knights, they do have a number of other defences against hostile stake-builders. We distinguish between pre-existing takeover defences, such as the voting restrictions that we documented in Section III.1, and defensive actions taken in response to the emergence of an

\footnotetext{
${ }^{16}$ This case demonstrates that the conventional view that a German house bank will defend its client from takeover is not generally accurate. In an interview with the Frankfurter Allgemeine Zeitung, Hilmar Kopper, chief executive of Deutsche Bank, said he had known of Krupp's planned takeover of rival steel group Hoesch beforehand. "It has my full support because it makes good industrial sense," Kopper said. In his view, Deutsche Bank (whose management board member Herbert Zapp headed Hoesch's supervisory board) had no obligation to defend Hoesch against the bid: "How [should Deutsche Bank have defended Hoesch]? Everyone knew someone was buying shares, but no one knew who. Secondly, why should Deutsche Bank defend Hoesch? Does Hoesch have a right to a defence? Or is Deutsche Bank obliged to maintain structures?"
} 
unwanted stake-builder. The main defensive actions are to forge a defensive alliance with friendly shareholders, seek the assistance of the house bank, line up a white knight, and reduce the stakebuilder's influence by denying him a supervisory board seat. As Table 7 shows, almost all the target companies in our sample attempted to forge (or maintain) a defensive alliance of friendly blockholders, perhaps as in the Dywidag case by entering into cross-shareholdings (by law, crossshareholdings cap each partners' votes at 25\%). As mentioned above, however, existing pooling arrangements frequently broke down when a rival coalition emerged. In most cases one or more of the pooling partners chose not to renew a pooling agreement, although there are some cases (such as Bopp \& Reuther) where a bid is initiated by the violation of an existing agreement. In a few cases white knights were sought by the incumbent management, in some cases apparently motivated, at least in part, by a desire to thwart a foreign suitor. This was certainly the case in the battle for BIFAB where the board "resisted a takeover by a foreign firm" and found a white knight in Langenscheidt, who ultimately took the firm private. Similarly, the attempted takeover of Boge by Italian rival Sogefi was resisted in favour of a German white knight (Mannesmann). However, white knight defences do not always work as expected. For example, Advanta adopted the role of white knight in defence of Dywidag against the unwelcome attention of Walter, but then sold the critical controlling stake to Walter!

The second main defence that we observe is denial of representation on the supervisory board. There are a few examples of such behaviour, which can certainly thwart blockholder attempts to change management or corporate strategy. However, in some cases where the initial goal of the stake-builder was "co-operation and influence" such denial by the target can provoke a full takeover. For example, the board of Goldschmidt denied major blockholders Veba and VIAG (who between them held nearly $46 \%$ of the shares) representation on the supervisory board. Initially Veba and VIAG were demanding a "change of direction" but their frustration ultimately resulted in VIAG assembling a controlling stake, without offering to buy out the family blockholders who had denied a seat on the supervisory board.

A more potent form of defence can, in certain circumstances, be the use of voting restrictions. These typically limit the proportion of votes that can be cast by any individual shareholder, or, in some cases, groups of shareholders operating under a pooling agreement. However, voting restrictions can also take the form of limited transferability of voting rights. As shown in Section II, such voting restrictions are quite common in Germany, and as Tables 5 and 6 show they are even more common amongst our cases. Indeed, in some of our cases they were the main obstacle to the hostile stakebuilder. For example, Continental had a restriction that no shareholder could exercise more than $5 \%$ 
of the votes. Not surprisingly, this resulted in numerous blockholders holding precisely $5 \%$ blocks. When the Pirelli bid emerged, a group of minority shareholders demanded an extraordinary general meeting to remove the voting right restriction. This required a simple majority and was duly carried. However, this decision was later over-turned in the courts when Continental alleged that Pirelli had acted in concert with its allies. ${ }^{17}$ The predator group should, therefore, have been subject collectively to a 5\% voting limit. Continental continued to deny Pirelli and its allies votes in excess of 5\% and this restriction was clearly critical in thwarting the attempted takeover. While it is not unheard of that a company institutes voting restrictions after a hostile stake-builder has emerged, as in the Feldmühle Nobel case, more usually restrictions are already in place. ${ }^{18}$

Voting restrictions are, however, much less potent as a defence when they are set at slightly higher levels. For example, the $15 \%$ voting right restriction in Hoesch's corporate charter was not an effective defence against Krupp. Such a restriction meant that it was only necessary for Krupp (with its $24.9 \%$ stake) to convince two other significant blockholders to vote in favour of removal of the voting restriction. One of these was WestLB, its house bank, who had a $12 \%$ stake but, significantly, at no stage declared its support for Krupp - thus avoiding accusations of acting in concert.

Surprisingly, Deutsche Bank, who also controlled about 12\%, also sided with Krupp despite being Hoesch's house bank. Hence, this case illustrates the significant difference between voting restrictions of 5\%, which can be a major impediment to hostile stake-builders, and restrictions of $15 \%$, which are typically much less effective in defending a target company. ${ }^{19}$ It also illustrates that a target cannot, as a matter of course, rely on its house bank for its defence. While Deutsche Bank successfully used its proxy votes to defend Continental, its proxies proved ineffectual in defending Feldmühle Nobel when shareholders decided to accept Stora's bid. In general, though, proxies do give banks both substantial influence (voting restrictions do not apply to proxy votes which are ultimately not owned by the banks themselves) and valuable information about changes in ownership which could be used to obstruct, or accelerate, a bid's progress.

\footnotetext{
${ }^{17}$ This information came to light when it emerged that Pirelli had entered into contracts with some of its allies guaranteeing to compensate them for any fall in Continental's share price. Fall it duly did (by around 45\%) and Pirelli's exposure became known when its banks exerted pressure to cover its position.

${ }^{18}$ A Frankfurt court recently ruled a contingent charter amendment inadmissible which would have allowed the Dresdner Bank management board to institute a $10 \%$ voting right restriction in the event of a hostile bidder emerging, subject only to the supervisory board's approval.

${ }^{19}$ Limiting the transferability of shares can also be a major impediment to a predator, as in the case of AGF's stake in AMB. In this case the court upheld the refusal of AMB's board to register the shares on the grounds that a board has a right to defend itself against a hostile stake-builder.
} 


\section{III.4 Outcomes}

In discussing the outcomes of the 17 control contests, we adopt three view points: those of the stakebuilders, the target companies, and minority shareholders. As we have mentioned, the stake-builders mostly operate in the same industry as their targets. This may help explain why, in a number of cases, their stated aim is to gain 'influence' (or, perhaps, co-operation) rather than majority control (see, for example, the AMB case). Such influence can manifest itself in a number of ways. Blockholders often seek seats on the supervisory board ${ }^{20}$, changes in management and changes in corporate strategy. Table 8 summarises the changes in control brought about by the stake-builders. Given their differing objectives (influence or control) and the fact that these are not hostile tender offers - where, at least in the UK, there is typically an unambiguous result—classification of outcomes requires some care. There were three cases where the target was generally successful in fighting off the predator. In two of these cases the Cartel Office effectively blocked the predator. In the third case (Continental) court decisions on voting restrictions were the decisive factor in thwarting the predator-though Continental's supervisory board nevertheless dismissed the CEO for his alleged intransigence in dealing with Pirelli's bid. In two of the 17 cases the stake-builder ultimately co-operated with the target in return for influence over corporate strategy and board representation. In both of these cases the CEO of the target firm resigned or was removed. Control changed hands in the remaining twelve cases. Of these, in six cases control was gained by the initial stake-builder; in two cases control passed to rival stake-builders (in one case after the initial bid was blocked by the Cartel Office); in another case a bank acquired a controlling stake which it then sold on to another company; and in two cases white knights (or, perhaps more accurately, grey knights) took control. In the remaining case (Wünsche), the stake-builders sold out to a new blockholder group once they had achieved their objective, namely to force the incumbent CEO (and dominant shareholder) to step down. This outcome was greeted with a $28 \%$ share price rise.

How did the control contests affect the performance of the target companies? Given our small sample size and the uncertainty about precise event dates, we cannot offer formal statistical tests. Instead, Table 9 offers an impressionistic glance at performance changes by comparing return on sales (RoS) and return on equity (RoE) in the three years before and the three years after the control contests began. On average across the sample, RoE hardly changed (11.3\% before, $12.5 \%$ after), but RoS nearly doubled (from $0.7 \%$ to $1.3 \%$ ). At the individual company level, nine firms increased their RoE and eight firms increased their RoS. Taken together, this is consistent with stake-building 
having some positive effect on target performance. On the other hand, the sign of the performance changes do not appear to correlate with the control contest outcomes: half of the cases in which control changed hands experienced a decline in RoS, while the other half saw an increase. So, to the extent that hostile stake-building has an effect on performance, it is unrelated to the final outcome.

In those cases where majority control was gained it is interesting to see how minority shareholders are treated. In common with legislation in the US, German corporate law neither requires that minority shareholders are made a buy-out offer ${ }^{21}$ nor that they receive 'equal treatment' in the terms offered. As can be seen from the final column of Table 8, in the few cases that tender offers have been made to minority shareholders, such offers have typically been at a significant discount to the price offered to block sellers in the course of gaining control. This contrasts with the US, where most of the blockholders investigated by Barclay and Holderness (1992) voluntarily buy out the minorities at a premium to the block price.

The difference in treatment between in the US and Germany could be due to Germany's much weaker protection for minority shareholders. Once a company gains majority control it is able to enter into a control and/or profit transfer agreement whereby the profits from the controlled company are effectively transferred to the parent. In practice, such an agreement is likely to require nearer $75 \%$ control as such schemes can be blocked if opposed by $25 \%$ of votes. The protection of minority shareholders in such controlled companies is notoriously weak. Subject to ensuring the economic survival of the dominated company a controlling shareholder can dilute minorities in a variety of ways. First, group losses can be foisted disproportionately onto minorities, while profits can be transferred out of the dominated company. Second, hidden reserves (typically land and share stakes whose book value is below market value) can be sold and the proceeds transferred to the majority owner. Third, group assets can be bought and sold at prices that are advantageous to the dominant shareholder. ${ }^{22}$ Fourth, while minority shareholders must be offered the alternative of a guaranteed fixed dividend should they wish not to sell out to the controlling shareholder, neither the bid price nor the guaranteed dividend need in any way be related to the share price, or the price the bidder

\footnotetext{
${ }^{20}$ Although, as can be seen in the Dywidag case, even a stake as large as $40 \%$ does not guarantee even a single seat on the supervisory board in the face of target opposition.

${ }^{21}$ We discuss below the possible impact of the new Takeover Code that was introduced in October 1995, which does have a requirement that minorities should receive an offer when majority control changes hands.

${ }^{22}$ For instance, minority shareholders in Volksfürsorge, an insurance company, recently suffered dilution twice within a short space of time. Volksfürsorge was first made to buy a stake in its parent's health insurance subsidiary which KPMG had valued using a particularly low discount rate of $2.9 \%$. Subsequently, Volksfürsorge was ordered to sell its legal insurance subsidiary to its parent who had commissioned a valuation on the basis of a much higher discount rate of $12 \%$ !
} 
paid to acquire control. ${ }^{23}$ Both options are, in most cases, relatively unattractive: Wenger and Hecker (1995) show that for 45 buy-out bids made to minority shareholders between 1983 and mid-1992 the price offered was $27.1 \%$ below the market price two days before the announcement.

We similarly find evidence that minorities are offered prices below the prevailing market price (or the price paid to gain control). In three out of the four cases where offers have been made to minorities the discounts have ranged from $15 \%$ to $64 \%$, although in one case (BIFAB) minorities were offered a $10 \%$ premium to the market price.

Many such offers (such as the Boge case we examine) result in lengthy litigation during which minority shareholders attempt to increase the attractiveness of the terms they are offered. The average court case takes 5.3 years to conclude (Wenger and Hecker 1995). There is, in general, no right of final appeal to the Supreme Court, which has led to different second-level courts of appeal passing contradictory verdicts, all of which have binding character. Neither the law nor the courts have established any consistent framework for valuing a company or assessing its risk. ${ }^{24}$ As to offers being made below trading prices, the courts have adopted the line that market prices are nothing to do with fundamental value-which can 'only' be found by accountants acting as expert witnesses. Even when the courts do find in the plaintiffs' favour, the average imposed increase in bid prices or guaranteed dividends of $25 \%$ (Wenger and Hecker 1995) is not sufficient to close the discount to the market price before the buy-out announcement. Finally, the law gives the majority owner explicitly the right to cancel the control and/or profit transfer agreement if the court's decision is unfavourable. ${ }^{25}$

The implications of these rules regarding minorities can be seen in the takeover of SEN by KW. Rival stake-holder APV had no realistic chance of taking majority control of SEN since KW owned $50.01 \%$. However, its $40 \%$ stake had considerable value as it could be used to block KW's merger with SEN. In some respects, blocking minority stakes (in excess of $25 \%$ ) can be used for green-mail: in the event, $\mathrm{KW}$ bought $\mathrm{APV}$ out at a premium to its purchase price and then proceeded to offer a

\footnotetext{
${ }^{23}$ There is a third option: minorities can be offered a certain fraction of the controlling parent's dividend, which, since the law does not specify what dividend policy the parent has to follow, allows for minorities to be diluted without any compensation whatsoever.

${ }^{24}$ One appeals court decided in 1990 that the compensation should be based solely on the basis of future cash flows, without regard to hidden reserves or other peripheral assets, both of which could be realised solely for the benefit of the majority shareholder. Recently, another appeals court chose a discount factor significantly above the risk-free rate to calculate the required minority compensation, after having used a discount factor below the risk-free rate in a previous decision.

${ }^{25}$ This option will be optimally exercised once the dependent company has insufficient capacity to generate enough cash to pay the guaranteed dividend post-dilution.
} 
coercive dilution deal to the remaining (non-blocking) minorities. The Feldmühle Nobel case similarly involved a substantially lower bid to minorities once Stora had gained control.

This ability to dilute the value of minority shareholdings does, of course, provide a powerful incentive for takeover and is likely to reduce Grossman-Hart (1980) free-rider problems. However, the sense of inequity resulting from such dilution frequently results in protracted law-suits, and is likely to have been a reason why the Ministry of Finance recently introduced its voluntary Takeover code, which limits (but specifically does not remove) the ability to dilute minority shareholdings.

\section{Conclusions}

In some countries, notably the US and UK, ownership of companies is dispersed and control is exercised, at least in part, through tender offers to shareholders. However, such a pattern of ownership is the exception rather than the rule. In many other countries, ownership is concentrated in large blockholders who, either individually or in coalition, exercise control. If the US/UK corporate governance problem is one of "strong managers, weak owners", as suggested by Roe (1994), in continental Europe, and many other countries, the corporate governance problem is rather one of "strong block owners, weak minorities". ${ }^{26}$ Whilst a theoretical literature on blocks has recently developed, there is little systematic empirical evidence on their importance or their impact on corporate control. This paper provides such evidence for Germany.

The paper challenges a number of conventional views of the way corporate control is exercised in Germany. First, there is a widespread belief that there is a very low incidence of hostile acquisition. Whilst there has, to date, been only one case of a hostile tender offer for a German company, we have documented a more important and common means of gaining control: through the building of hostile stakes. Given the pattern of ownership of German listed companies (summarised in Section II), with around $87 \%$ of firms having at least one blockholder owning $25 \%$ or more, it is not surprising that a relatively active market exists in stakes, both for liquidity reasons and for friendly as well as hostile changes in control. We identify 17 cases over an eight-year period that can be classified as hostile stake-building. At first sight this may look like an insignificant threat. However, our analysis of the ownership structure of German companies suggests that the number of firms facing a realistic risk of hostile acquisition may be as low as 64 . This suggests a much higher

\footnotetext{
${ }^{26}$ This point was noted by Patrick Bolton.
} 
incidence (at around 3-4\% per year) of hostility in Germany than has previously been suggested, and is of a similar magnitude to the incidence of hostile takeovers in the UK.

Second, we have illustrated the complex role that banks can play in corporate governance. The dominant role accorded to German banks in much of the academic literature is as major providers of finance and also - via their representation on supervisory boards, their direct equity ownership and their control of proxy votes - as important monitors of corporate performance. We believe that this stereotype is, at best, only partially accurate. There is growing evidence that banks do not provide a higher proportion of finance for investment in Germany than elsewhere, and that the effectiveness of the monitoring role has often been overstated ${ }^{27}$. In this paper we identify another important role for banks, namely their role in assisting companies pursuing a strategy of hostile stake-building. We document many cases where banks play a pivotal role in building, brokering and concealing stakes. In contrast, it is striking how few examples we find of banks actively defending target companies from a hostile stake-builder. Such behaviour may, of course, be compatible with the view that banks actively monitor German companies and help to effect changes in corporate governance in the case of failing firms. However, it is important to recognise that this role is performed not by the companies' house banks (who are often believed to be acting as monitoring intermediaries drawing on their privileged information), but by the banks assisting the predator. This role has not previously been recognised.

An important question remains: given the ownership structure that exists in Germany, how efficient is the system of corporate control we observe? A full answer is beyond the scope of the present paper, but there are certainly a number of areas of concern. First, the ability of a controlling blockholder to expropriate minorities could significantly raise the cost of capital. It is interesting to observe that the recently introduced Takeover Code in Germany-the adoption of which is voluntary $^{28}$ for firms - makes some attempt to protect minorities. Companies acquiring stakes in excess of 50\% are now required (provided they have adopted the Code) to make an offer for the

\footnotetext{
${ }^{27}$ See, for example, Rajan and Zingales (1995) Corbett and Jenkinson (1996) and Edwards and Fischer (1994). ${ }^{28}$ By September 1996, one year after it came into force, only around one-third of listed companies in Germany had actually adopted the Code. The Takeover Commission reviewed twelve cases in its first year, only one of which led to a public censoring.
} 
outstanding shares, but the regulations regarding the terms of such offers provide very little, if any, additional protection for minorities and are far weaker than those operating in other countries. ${ }^{29}$

Second, corporate governance in Germany is both unpredictable and lacking in transparency. Battles often involve a protracted, and clandestine, shuffling of stakes between rival coalitions and the revising of pooling agreements. Even large blockholders can find themselves, without warning, as members of the suppressed minorities. Furthermore, once a hostile stake-builder appears there is frequent recourse to the courts, whose decisions are, on occasion, unpredictable and lack consistency. As a result, some of the bids considered in this paper took over 5 years to reach their conclusion. If a guiding principle for the design of corporate governance systems is reasonable speed and certainty, the German system frequently fails to achieve either.

The market for stakes is likely to become more liquid in the future. Banks are, in general, reducing their stakes in companies, in response to tax changes and a general shift in opinion regarding their role in corporate governance. The latter has many roots: the recent string of embarrassing failures of control and monitoring at Schneider, Balsam, Metallgesellschaft and Klöckner-Humboldt-Deutz; the

\footnotetext{
${ }^{29}$ A party which acquires a stake in excess of $50 \%$ (via open-market purchases or a private deal) must offer to buy out minority shareholders unless the acquiring company has merged with the target company or entered into a profit transfer and/or management control agreement within the first 18 months after gaining control. In the absence of a merger or control agreement the controlling company is required to make a public offer for the remaining shares within the next three months. If, during the initial 18 month period after having gained control, the acquiring company has not bought additional shares the price offered to minorities must not be less than the price paid on purchases during the six months before gaining control minus $25 \%$ (denote this price $\mathrm{P}_{1}$ ). If the acquiring company has made additional purchases since gaining control the price offered to minorities must be the maximum of $\mathrm{P}_{1}$ and the weighted average of the prices paid on such additional purchases. To those who have grown accustomed to observing bid premia being offered to shareholders in the event of a takeover such arrangements will hardly appear too onerous for the bidder! This contrasts, for example, with the UK City Code on Takeovers which demands a full bid once a shareholder obtains a stake in excess of $30 \%$, at a price no worse than the highest price that the bidder paid during the previous 12 months.
} 
increasingly global financial outlook of many large German companies; and the new focus on shareholder value permeating many German companies and banks. As banks reduce their stakes, and their influence over corporate governance, cases of hostile stake-building will surely increase. An important gap in the existing theoretical literature is the analysis of control battles where multiple large blocks exist, and this remains an area for future research. 


\section{Appendix}

Aachener und Münchener Beteiligungen (AMB)

The control contest began when French insurer AGF built a $25 \%+1$ share stake in a bid to become "actively involved in insurer AMB's management", but was rebuffed by AMB's board who refused to register AGF's votes (though the board could not prevent AGF from voting Skandia's 1.8\% stake with whom AGF was acting in concert). AGF's legal challenge against AMB's refusal to register failed in a lower court on the grounds that a "board has a legitimate duty to defend itself against a hostile takeover." Part of AMB's cross-shareholdings unravelled when Royal Insurance decided to sell its $18.8 \%$ stake. Fondiaria, the third party to the original crossshareholding structure, exercising its right of refusal, bought part of this stake (at a 5.5\% premium over the market price), increasing its $6 \%$ holding to $21 \%$. Meanwhile, another $10 \%$ block came on the market which AMB was eager for another German insurer, Volksfürsorge, to buy (AMB had recently acquired a majority interest in Volksfürsorge thanks to Fondiaria). Hostilities ended when the chairman of AMB's supervisory board brokered a deal with AGF, against the opposition of his own CEO, who subsequently resigned. The peace agreement entailed a partial registration of AGF's votes, operational co-operation, and a commitment by AMB to take a 5\% noyeau dur stake in AGF in preparation for AGF's planned privatisation. Fondiaria, opposed to AGF's accommodation, sold its $21 \%$ holding to a consortium of German banks and insurers (in preference to AGF's counter-offer). These German institutions then controlled 38\%, in response to which AGF increased its stake to $33.55 \%$ via purchases from UK institutional investors (at the time, a draft EC Directive muted harmonising the blocking minority threshold to $331 / 3 \%$ ). Following subsequent skirmishes between AGF and the German institutions over the chairmanship of the supervisory board, AGF finally entered into a standstill agreement not to increase (or decrease) its block (with a registered 27.49\% of the votes) until December 1999, forestalling — at least for some time—a majority takeover of AMB.

Asko

The control contest began when rival retailer Metro increased its declared (and indeed so far friendly) $10 \%$ stake in open-market purchases, while two close allies of Metro (including its house bank) also held 10\% each. Asko's supervisory board chair (who was CEO for 18 years and founded the firm) opposed Metro's bid for control, despite Asko's financial difficulties. In an attempt to fight off the predator, Asko revealed that 50\% of the votes in its main trading subsidiaries were held by a foundation close to members of its supervisory board, implying that a new owner could not control Asko's operations. (This was part of a defence structure erected in response to two hostile takeover attempts by rival retailer co op AG in 1978 and 1981.) Asko itself had a 5\% voting restriction. The battle ended once the supervisory board removed its chairman in a vote of confidence, unravelled the special rights of the foundation, and removed the voting right restriction. Metro then increased its stake to $55 \%$, in the open market and from other blockholders (believed to be its associates though the sellers' identity was never confirmed).

\section{Axel Springer Verlag}

The control contest began when, following the flotation of the company and the death of its founder, three rival blockholders emerged at this publishing house: the family (which though in a minority controlled the boards), the Burda brothers Franz, Frieder and Hubert (to whom the late founder had tried to give majority control, which was blocked by the Cartel Office), and an outsider, Leo Kirch. Initially, Franz and Frieder Burda cooperated with the family to contain Kirch's influence, denying him a seat on the supervisory board and not removing the CEO, as he demanded. Then they surprisingly agreed to pool their $25.9 \%$ stake with Kirch's declared $10 \%$ and his undeclared option on a further $16 \%$, giving the new coalition majority control. Only a month later, however, Franz and Frieder Burda sold their block to the family. The family was not yet safe, though: claiming he had first refusal on his brothers' stake, Hubert Burda challenged the sale in court. As defensive measures, the Springer family refused to register Kirch's additional $16 \%$ of votes, signalled they would not register Hubert's block should he win in court (which he finally did not), and entered into a crossshareholding agreement with Monti of Italy. (In a further twist, the family and Monti later fell out, with Monti threatening to sell its $10 \%$ to Kirch.) Eventually, Kirch and the family came to an arrangement, electing first one of his associates and later Kirch himself onto the supervisory board. Throughout the ten years of control battles, there was extremely high turnover amongst top executives, including four fired CEOs in one twelve-month period. 
The control contest began when Maxwell Communications Corp. plc privately approached BIFAB's board with a takeover offer at a 53\% premium to the share price. At the time, there were three blockholder groups: the Brockhaus family with around $15 \%$, its pooling partner the Meyer family with around 38\%, and Rheinpfalz Verlag with $27.34 \%$. While it is not known what prompted Maxwell's bid, the fact that the Meyer family did eventually sell out hints at either of: (i) its desire to divest its stake for some unknown reason, which put BIFAB in play and prompted Maxwell's bid; (ii) the imminent breakdown of the controlling coalition of the two families; or (iii) the possibility that the large premium Maxwell was willing to offer tempted the Meyer family into considering a sell-out. BIFAB's board responded to Maxwell's approach by saying it "resisted a takeover by a foreign firm" and was reported to be looking for a (German) white knight to stave off Maxwell's "hostile takeover bid". The Brockhaus family added to this opposition claiming it would not sell under any circumstances, nor would it tolerate a sale to Maxwell by the Meyer family. A white knight was quickly found in rival publishing house Langenscheidt KG, which bought the Meyer family's 38\%, giving it majority control in coalition with the Brockhaus family (whose patriarch joined Langenscheidt's board). Langenscheidt shortly afterwards increased its stake to $65.34 \%$ by buying out Rheinpfalz. One year later Langenscheidt and Brockhaus jointly took BIFAB private; the buy-out offered minority shareholders a $10 \%$ premium to the trading price.

\section{Boge}

The control contest began when rival car-parts company Sogefi SpA, controlled by Carlo de Benedetti, emerged as the holder of a $24.9 \%$ block in Boge, assembled in the open market. In response to Sogefi's acquisitions and newspaper speculation that De Benedetti sought a majority stake, Commerzbank and Boge's industrial partner VDO Adolf Schindling, who at Boge's flotation 18 months earlier had each taken a 10\% stake, increased their stakes to $15 \%$ and $17.5 \%$, respectively, and claimed that they, together with an unnamed third blockholder, controlled a majority of Boge's votes. Both Boge and VDO rejected Sogefi's proposal for a three-way merger, stating they wished to remain independent. At Boge's subsequent AGM, Sogefi disclosed an increased stake of $28.3 \%$, which they increased to over $45 \%$ over the following year. Meanwhile, doubts had emerged over the actual existence of that third blockholder and thus over Boge's ability to muster a friendly majority coalition against Sogefi. Boge's management eventually placed a $6 \%$ stake with its US joint venture partner, TRW Inc., openly expressing its preference for closer co-operation with TRW over Sogefi. When Sogefi further boosted its stake, to $47.88 \%$, Commerzbank revealed that a friendly pool now controlled a slim majority: Commerzbank (24\%), VDO (17.6\% plus $2.5 \%$ held by its Swiss subsidiary) and TRW (6\%). Free float at this point was a mere $2 \%$, down from $80 \%$ when the company went public three years earlier. When over the following year the cooperation with TRW went sour and TRW put its stake up for sale, Commerzbank sought a friendly buyer of the $50.1 \%$ pooled block. (TRW's $6 \%$ was clearly pivotal. However, it is likely that TRW was prevented by the pooling contract from selling it to the highest bidder if that bidder was unacceptable to its pooling partners.) One bidder, US car parts group Arvin Industries, was publicly rebuffed, prompting Arvin to consider a public counter-offer or to buy Sogefi's near-majority block. Interestingly, while Boge's management favoured Arvin as its new majority owner, its current majority owners, led by Commerzbank, instead sold their stakes to Mannesmann (to whom Commerzbank shortly afterwards also brokered the sale of VDO) at an undisclosed price in a deal described as "a defensive measure to prevent De Benedetti from taking over". A few months later, Sogefi also sold its stake to Mannesmann. Mannesmann proceeded to offer to buy out the remaining $2 \%$ minority shareholders, at a 64\% discount to the price it paid Sogefi, offering one Mannesmann share for every two Boge shares (1:2). Though a shareholder lawsuit aimed at annulling the forced integration of Boge was unsuccessful, Mannesmann nevertheless increased its offer to 1:1 plus a cash payment of DM80/Boge share. The control contest lasted 2.5 years in total.

\section{Bopp \& Reuther $(B \& R)$}

The control contest began when IWKA AG acquired a $42.9 \%$ block from a group of family shareholders following years of poor performance. Two years earlier, the family owners of B\&R had sold a $25.1 \%$ stake to financial investor Hannover Finanz GmbH (HF) in preparation for a possible subsequent stock market listing. The twenty-odd family shareholders and HF had signed a pooling agreement which secured pre-emptive rights over share stakes and "a say in any important decisions affecting the company's future". This pooling agreement was violated when some family members sold their $42.9 \%$ block without notifying either the company's board nor their pooling partners. Hinting at resistance against IWKA's intrusion from the remaining $32 \%$ family blockholders (led by B\&R managing director Carl-Friedrich Reuther), IWKA affirmed its wish to majoritycontrol B\&R and to "exercise its influence on the management or supervisory board with a view to improving the company's poor operating performance", and consequently offered to buy out the remaining shareholders. 
B\&R's board countered by pointing out that a $54 \%$ majority was still bound via a pooling contract between some of the remaining family shareholders and HF (though that contract was due to expire within eleven months and even the board had to admit that the pool did not agree on the desirability of IWKA's new stake; the 54\% figure also suggests that $3.1 \%$ of the family holdings did not rally around Reuther's defence). Reuther himself was engaged in negotiating the sale of the combined $54 \%$ block held by the remaining family shareholders and HF to Britain's Siebe plc. (It later emerged that the family had offered to buy out HF at $170 \%$ of book value, and that Siebe's $195 \%$ bid for the 54\% majority stake valued the company more highly than IWKA's $180 \%$.) However, within two weeks, IWKA had secured HF's support (in spite of the latter's pooling commitment) and intended to dismiss B\&R's board at the forthcoming extraordinary annual meeting. The deal with Siebe fell through once HF switched its support to IWKA, and HF was later sued by family members for violation of the pooling contract (the outcome of this suit is unknown). Following the EGM, the remaining family shareholders gave up and sold their $32 \%$ stake to IWKA at the lower price of $180 \%$ of book value. IWKA exchanged the management, began to restructure the company, and a few years later also bought out HF.

\section{Buderus}

The control contest began shortly after Metallgesellschaft floated its $79.9 \%$ stake in Buderus in a public offering lead-managed by Deutsche Bank and co-managed by Dresdner Bank and Commerzbank with a mandate to spread the shares widely. At the time of the book-building Buderus announced that a number of institutional investors had taken stakes of between 1 and $3 \%$ and jointly (though not in coalition) controlled a majority of votes. Buderus' management welcomed the fact that the company no longer had a majority owner; it is known that Buderus' management and Metallgesellschaft had considered selling to a single investor instead of placing the shares in the market, but that this option had been rejected to ensure Buderus' independence. However, shortly afterwards Commerzbank and Dresdner revealed they had each taken a 10\% stake "as a longterm financial investment and not for resale to potential takeover bidders". A month later Bilfinger und Berger (B\&B) revealed at Buderus' AGM that it had assembled a 15\% block and planned to discuss its long-term strategic vertical involvement with Buderus' management. While Buderus did not openly condemn the emergence of this block, its management did declare their intention to keep the company independent of outside influence (curiously motivated as being in the interest of Buderus' core customers!). Significantly, Dresdner Bank acts as B\&B's house bank, is its only declared blockholder (25.1\%), and chairs its supervisory board. This constellation led to speculation that Dresdner Bank had facilitated the assembly of B\&B's 15\% stake (possibly in connection with the IPO) and might have taken its own 10\% stake for the benefit-if not on behalf of-B\&B. Not surprisingly, therefore, B\&B applied to the Federal Cartel Office to increase its Buderus stake to $25 \%$, prompting Buderus to declare that it could not see any synergy gains and did not need B\&B as a strategic partner. Only once the Cartel Office ruled against the stake increase did Buderus soften its tone and entered into a dialogue with its $15 \%$ shareholder and supervisory board member B\&B. To date B\&B has not divested its Buderus stake.

\section{Continental (Conti)}

The control contest followed a year of heavy trading (7.6 times total Conti share capital) and persistent stock market rumours - repeatedly denied by Conti and the subsequent bidder, Pirelli-that a takeover bid was imminent. In the run-up to Pirelli's intentions being confirmed, the Italian tyre manufacturer-faced with worldwide over-capacity in the tyre industry-privately approached Conti with a merger proposal, and reportedly received encouragement from two members of the supervisory board: Ulrich Weiss, of Deutsche Bank (Deutsche Bank was Conti's house bank, chaired the supervisory board, and held 5\% of its shares) and Friedrich Schiefer, a management board member of 5\% shareholder Allianz, the insurance company. Having assembled a 5\% stake in open-market purchases, Pirelli eventually announced its bid for control in the form of a reverse takeover by Conti of Pirelli's tyre division, adding that it had already secured the support of an unnamed majority of Conti's shareholders; Conti's share price fell by 7\%. Pirelli was at pains to stress that its proposal was friendly. Behind the scenes, Conti CEO Horst Urban enlisted Morgan Grenfell (Deutsche's investment banking division) to advise on the takeover defence and lobbied his board to reject the proposed merger. Urban also promised his unions that there would be no redundancies if Conti stayed independent—which is a significant form of defence as employee representatives controlled half the supervisory board. Though allegedly originally in favour of Pirelli's approach, supervisory board chairman Weiss helped defeat (with the votes of the employee representatives) the other board members' suggestion that management be instructed to negotiate with Pirelli. Urban then publicly declared the proposal "a hostile takeover attempt, despite all assurances to the contrary." The share price continued to fall. Over the following few months, stakes of up to $5 \%$ each were disclosed by some of Pirelli's backers, including two of Pirelli's own shareholders (Italian merchant bank 
Mediobanca and Sopaf SpA), Fiat, Allianz' Italian subsidiary and Merrill Lynch, Pirelli's advisors. After an unusually public war of words, Conti demanded a standstill agreement as a precondition for talks, including a commitment that Pirelli abstain from attempting to remove Conti's 5\% voting right restriction. Pirelli rejected this demand. Morgan Grenfell was actively engaged in finding a white knight or at least a $25 \%$ blocking coalition, a solution publicly favoured by Urban. Pirelli had still neither named its alleged majority supporters nor launched a public tender offer. Events took an unexpected turn when a group of minority shareholders demanded an extraordinary general meeting to repeal the voting right restriction (which required a simple majority) and force a decision on the merger proposal (which required the approval of $75 \%$ of votes at the EGM). Deutsche Bank and Morgan Grenfell put together a defensive coalition of banks, proxy votes and car manufacturers large enough to block the merger proposal: Daimler Benz (in which Deutsche Bank held a 28.3\% stake and whose supervisory board it chaired), Volkswagen (whose CEO was Urban's predecessor at Conti), and BMW; Conti's share price fell by 5.5\%. Nevertheless, at the EGM the voting restriction was overturned with a $65.97 \%$ majority (though this was later to be opposed in the courts by a minority shareholder as well as Conti itself); Conti's share price rose 5.2\%. Conti still vowed to defend its independence. Interestingly, the arithmetic of the EGM indicates that Pirelli did not in fact control a majority of votes. Shortly afterwards Conti's supervisory board relieved CEO Urban of his duties reportedly for his continued opposition to talks. Unconditional talks were resumed and continued over the next eight months, though the management board was still publicly divided on the merits of a merger. Conti began to restructure by closing overseas factories and selling off non-core divisions. Just before a cross-shareholding deal between Conti and Pirelli was to be announced, it emerged that Pirelli had given its backers indemnity guarantees to reimburse any losses on Conti shares. As Conti shares had lost roughly $45 \%$ of their value since Pirelli and its partners bought their stakes, Pirelli came under pressure from its banks to find funds to cover its position and was eventually forced to call off the deal and restructure and refinance its balance sheet. However, Pirelli also bought options on its allies' combined 32.4\% in Conti. At that point, Conti appealed to the courts alleging Pirelli had broken securities laws by acting in concert and not disclosing the contracts with its allies. This challenge, later accepted by the court, invalidated the EGM's decision to remove the voting right restriction. Over the next four moths, new Pirelli allies bought stakes in Conti and Pirelli tried again: at the next AGM it moved to have the restriction lifted, a proposal deemed "hostile" by Conti's new CEO who called Pirelli's intentions "sinister". Conti refused to let Pirelli and its allies vote all their shares at the AGM, on the grounds that they constituted a concert party and as such were limited to 5\%; Pirelli's motion was defeated, though Pirelli managed to obstruct Conti's proposed capital increase. When finally a superior court resurrected a decision of a pre-bid AGM to raise the majority required to remove the voting right restriction from $50 \%$ to $75 \%$, Pirelli gave up and let its $5 \%$ stake and the options it held be placed by Deutsche Bank with German companies friendly to Conti. These placements were supported by a financial guarantee from the state of Lower Saxony where Conti is headquartered. The control contest lasted 2.5 years in total.

Deutsche Beamten-Versicherung (DBV)

The control contest began soon after public-sector insurer DBV was privatised via a public offering of 50\% minus 2 shares. The IPO was lead-managed by Commerzbank which not only took a $25 \%+1$ share stake (another 25\% + 1 share block still being in the public sector) but also bound itself not to increase the size of its block and agreed that DBV was to remain independent. One way to ensure independence was the choice of restrictedly-transferable shares which require the board's registration before votes can be exercised. However, when DBV's share price soon began to fall below the offer price, Commerzbank, perhaps in an effort to support the share price, acquired a further $23.3 \%$ over the following few months from an unnamed investor. This stake increase ostensibly had the approval of DBV's board, and anyway was accompanied by Commerzbank's pledge not to have the votes of the additional shares registered, its assurance that the overall stake would be reduced back to $25.1 \%$ in due course, and, it appeared later, its agreement that DBV could veto Commerzbank's choice of buyer. When Zurich Insurance emerged as a possible buyer, DBV's management expressly declared they would block any attempt at a hostile takeover and that they would not allow any shareholder to build up a majority or dominant stake - which would seem a credible threat given (i) the restrictions on votes, (ii) the free float of below 50\%, and (iii) Commerzbank's earlier commitment to ensure DBV's independence. The talks with Zurich Insurance collapsed, partly because DBV opposed Zurich Insurance's insistence on majority control. Four months later, in spite of its long-standing commitment not to hold more than a blocking minority stake, Commerzbank increased its stake to $50 \%+1$ share via open-market purchases. Once it controlled DBV, the bank swiftly proceeded to sell majority control to Winterthur, a Swiss insurer. As DBV's CEO was chosen to head all of Winterthur's German subsidiaries, it seems unlikely that DBV objected to the sale; however, since Commerzbank had acquired majority control opposition on DBV's part was, one presumes, no longer an attractive proposition. 


\section{Dyckerhoff und Widmann AG (Dywidag)}

The control contest began at a time when Dywidag's ownership structure was highly fragmented, with a maximum free float of only $21 \%$ and the two largest blocks owned by Holzmann AG, a rival construction company whose shareholding was viewed as friendly, and industrialist Max Aicher. During the late 1980s, Ignaz Walter, acquisitive owner of several regional construction companies, embarked on what he later called a 'strategy of slow takeover' of Dywidag by clandestinely buying up minority blocks from various sources, including a stake held by his house bank, Bayern LB, and $2 \%$ bought on the open market. While there was speculation that Walter was behind the stake purchases, he repeatedly denied being a blockholder in Dywidag. By the end of 1991, Walter controlled 40\% of Dywidag's votes, which he had previously failed to declare, and explicitly denied having; it appears that technically he never crossed the $24.9 \%$ disclosure rule simply by spreading the $40 \%$ stake over various associated parties, including his children. Once Walter declared his stake as well as his intention to take over the company, Dywidag's management strongly and publicly resisted his hostile endeavours. Despite being the largest shareholder, Walter was denied a seat on the supervisory board. In December 1991, a financier called Dieter Bock proposed a "friendly" takeover of Dywidag, a move that was welcomed by the board. Rather than inviting all Dywidag's shareholders to tender their shares, Bock proposed to consummate the takeover via the negotiated friendly acquisition of two key shareholders' large stakes: the $24.9 \%$ stake held by Holzmann, and the Aicher block, which by now had been increased to $24.7 \%$, along with the small stake owned by Dumez of France via a cross-shareholding arrangement. This 51\% stake would block the $40 \%$ stake owned by Walter. However, events did not turn out as expected. Bock duly acquired the Holzmann stake, but then announced, in May 1992, that Advanta had failed to complete the assembly of a controlling stake in Dywidag, blaming Max Aicher for reneging on the sale contract (a view disputed by Aicher). Bock also disclosed that Advanta had sold the 24.9\% stake in Dywidag it had acquired from Holzmann to Walter, finally giving Dywidag's hostile suitor majority control! Dywidag's CEO resigned. No buy-out offer was made to minority shareholders. The Cartel Office subsequently fined Walter DM500,000 for failure to register changes in its ownership interest in Dywidag.

\section{Feldmühle Nobel (FeNo)}

The control contest began when the Flick brothers Friedrich Christian and Gert-Rudolf (the former owner's grand-nephews) accused the management of not maximising the sale price of various assets. When a hostile tender offer was rumoured, FeNo's management restricted voting rights to a maximum of 5\% per shareholder, aided by Deutsche Bank which controlled about 55\%, mostly via proxies but also via its $8 \%$ stake in FeNo. A year later, the Flicks and five associated parties sold a previously undisclosed $40 \%$ block (assembled with the help of Merrill Lynch via open-market purchases and secret direct agreements with institutional blockholders) to Veba AG, which Veba then boosted to 51\%. However, when Veba failed to remove the 5\% restriction and take control of FeNo, the Flicks assembled another stake of between 10 and $20 \%$ and began to oppose Veba for not launching a full bid. The Flicks' actions are consistent with a strategy of trying to maximise the bid value in the ensuing auction, which they were well-placed to do given that their 10-20\% stake, spread over several parties, gave them more clout than Veba derived from its 51\% stake. Two further suitors emerged in the form of Sweden's Stora Kopparberg and SCA, both of which bid for the company. Veba eventually sold its block to Stora, who also bought out the block jointly held by the Flicks and Merrill Lynch as well as SCA's 5\% toehold stake. Once Stora owned $85 \%$, minority shareholders were offered a buy-out price $15 \%$ below the bid price paid to Veba. The firm was split up and restructured, in spite of the management's opposition. The control contested lasted 15 months.

\section{Th. Goldschmidt}

The control contest began when two conglomerates, VIAG and Veba, independently and potentially in rivalry, bought stakes from an existing corporate shareholder and part of the family. When management and the remaining family shareholders affirmed their desire to remain independent, the new blockholders pooled their 45.8\% stakes and demanded "a change of direction", but were kept at bay by the insiders who refused to grant representation on the supervisory board. The contest was resumed when (i) Veba came under pressure from its shareholders to sell its $27.95 \%$ stake (25.02\% of votes) and (ii) the family's coalition with insurer Allianz broke down, when Allianz chose to let its pooling contract (via which the family controlled the firm) expire in 1996 and put its $10.38 \%$ stake (9.29\% of votes) on the market. VIAG beat the family to both stakes, and in April 1997 controlled $50.34 \%$ of the votes to the family's $39.94 \%$. No offer to the minority shareholders was made. The control battle lasted five years in total. 


\section{Hoesch}

The control contest began when high trading volumes in Hoesch shares throughout 1991 prompted speculation of a possible (foreign) takeover bid. In October 1991 Krupp, a rival steel maker, revealed it had bought a $24.9 \%$ stake secretly accumulated on its behalf by Credit Suisse. Hoesch's share price fell by $9.7 \%$ in response, while Krupp's rose by $8.6 \%$. Krupp made clear its intention to acquire a majority block, a plan for which it claimed to have received the prior support of various banks and financial institutions with holdings in Hoesch. One of these was WestLB, Krupp's house bank and chair of its supervisory board, which declared it had a 12\% Hoesch stake on its trading books, though it denied to have pledged the shares or the votes to Krupp. This is not altogether surprising, since a formal agreement would have reduced Krupp's influence given Hoesch's corporate charter which capped the votes of any stake or formal pooling of votes at $15 \%$. Deutsche Bank was Hoesch's house bank and chaired its supervisory board. Nevertheless, there were persistent rumours that Deutsche Bank controlled a block of perhaps $10 \%$ which was friendly to Krupp! Krupp's CEO, Gerhard Cromme, was at pains to stress this was no hostile bid, but a defensive move as Krupp would have suffered had Hoesch been taken over by a (foreign) rival. The initial reaction from Hoesch's management was muted with no particular indication of opposition, except perhaps grumblings about not having been informed until a few days before Krupp made its public announcement. Initially, it was only Hoesch's unions which called Krupp's bid a hostile takeover. Hoesch's CEO, Kajo Neukirchen, subsequently developed a more confrontational tone in public, and eventually Hoesch's supervisory board declared its opposition to the clandestine nature of Krupp's stake building, though it was in principle willing to consider merger plans on the basis of a voluntary discussion amongst equals. At the same time, it took the unusual step of suspending two members of the management board who were believed to favour Krupp's bid, widely seen as a hardening of positions. For a brief moment, it looked as if British Steel might step in as a white knight to rescue Hoesch. Krupp's Cromme reacted by noting that he would take over Hoesch whether or not Hoesch co-operated. Significantly, he also claimed Deutsche Bank had been notified of the impending bid some two weeks in advance, and had welcomed it, which contradicted Deutsche Bank's public insistence on its uninformed and neutral role. When Hoesch demanded evidence of Krupp's alleged majority coalition, Cromme provided notary evidence of the support of a further $30.4 \%$ of the votes, including a $20 \%$ block held at Credit Suisse, but excluding WestLB's $12 \%$. Shortly afterwards, Krupp announced it had bought a further $26 \%$ (likely to have included at least part of Credit Suisse's $20 \%$ stake) at an undisclosed price, thus increasing its $24.9 \%$ stake to a majority block; Hoesch's share price fell by $4 \%$. Krupp had still not made a formal tender offer. Over the next few months, Krupp and its allies removed the voting right restriction, sealed a merger agreement and saw off legal challenges from three minority shareholders. Amongst its allies were not only WestLB, its own house bank, but also Deutsche Bank, Hoesch's house bank, which controlled an estimated 12\% of Hoesch via proxies. Hoesch's CEO Neukirchen resigned. Krupp's CEO Cromme was elected "Manager of the Year" by TopBusiness and Manager Magazin. The contest only lasted a few months.

\section{Philipp Holzmann AG}

The control contest began when Advanta GmbH, a company controlled by financier Dieter Bock (see above: Dywidag) announced it had acquired, from an unnamed source, a 10.25\% stake in Holzmann, Germany's largest construction company by turnover. At the time, a key $20 \%$ Holzmann shareholder was Hochtief AG, Germany's second-largest construction company. Bock's ultimate intentions were unclear until Advanta sold its stake to BfG, one of its house banks. That BfG simultaneously granted Hochtief a call option on the stake only became apparent when Hochtief notified the Federal Cartel Office of its intention to raise its 20\% stake via exercising the BfG option, thus triggering a mandatory anti-trust review. Furthermore, Hochtief declined to rule out increasing its stake further, raising the spectre of a takeover. While analysts welcomed the potential bid, Holzmann's board issued a statement reaffirming its commitment to remaining independent. At the same time there was speculation — first denied and later confirmed — that Deutsche Bank, Holzmann's house bank, dominant shareholder and chair of supervisory board, was willing to contemplate reducing its $25.9 \%$ to $10 \%$, thus deserting its client (Deutsche Bank was doing brisk trade with Hochtief's majority owner, RWE). Holzmann's main line of defence, therefore, was the anti-trust card which duly paid off: the Cartel Office ruled against Hochtief on competition grounds, blocking any future increase in Hochtief's Holzmann stake from the pre-bid level of $20 \%$. Hochtief arranged for Commerzbank, its house bank and minority shareholder, to purchase the $10.25 \%$ block from BfG, paid Commerzbank an undisclosed fee to finance the cost of carry, and eventually signed a purchase agreement for the stake with Commerzbank contingent on Hochtief winning its appeal against the Cartel Office's ruling before the superior court in Berlin. When these transactions came to light, the Cartel Office started an investigation into the legality of Hochtief's dealings with Commerzbank and 
BfG, threatening the three companies' managers with fines of up to DM1m each. Simultaneously, Hochtief also purchased the $4.9 \%$ stake in Holzmann which Commerzbank had acquired 13 years earlier. In a filing with the Cartel Office, Hochtief later disclosed it had held a call option on the $4.9 \%$ stake all along, though neither Hochtief nor Commerzbank had previously disclosed this. Indeed, Commerzbank had declared the disputed stake as its own until the very onset of hostilities, thus helping Hochtief obscure its true ownership interest in Holzmann. These revelations followed assurances by Commerzbank and Hochtief that there were no undisclosed stakes or contracts pertaining to such stakes; Commerzbank and Hochtief only eventually disclosed their contractual arrangements due to requirements under the new securities trading law. Pending Hochtief's appeal, the control contest is still open.

\section{Kolbenschmidt}

The control contest began when $\mathrm{T} \& \mathrm{~N}$ plc acquired options on a combined $52.5 \%$ block after financially troubled Metallgesellschaft put its $47 \%$ block on the market (the remainder were options on $2.5 \%$ from Magna International of Canada, and 3\% from institutions which held a combined stake of 10\%). As a horizontal merger, the deal was subject to Cartel Office approval. Within three months target management asserted their desire to remain independent of any majority shareholder, sought a different, friendly, but minority buyer (Dana, Inc.) for a $25 \%$ block, and organised a workforce petition in protest against T\&N's planned takeover. Due to Cartel Office opposition and problems over its UK asbestos liabilities, T\&N failed to exercise its options by their expiry, prompting its bank, Commerzbank, to acquire a total of $49.99 \%$ on T\&N's behalf and grant T\&N a new option (Magna's 2.5\% option was extended). Shortly afterwards, the Cartel Office blocked the deal and $T \& N$ appealed. After a further options extension, T\&N appealed - unsuccessfully - to the EU competition authorities to overrule the German decision. Finally, Commerzbank placed half of its stake with Rheinmetall, another car parts maker, which subsequently received Cartel Office clearance to take management control of Kolbenschmidt. Within a few months, Rheinmetall took management control by purchasing T\&N's option on the remaining $24.99 \%$ stake still held by Commerzbank and buying a further $3 \%$ in the open market. No buy-out offer to minorities has so far been announced.

\section{Seitz-Enzinger-Noll (SEN)}

The control contest began when SEN's minority shareholders, and then its own board, objected to the forced merger with a division of its $50.01 \%$ parent, Klöckner-Werke (KW). In that climate, APV plc managed to acquire a $40 \%$ block from a local savings bank (BaKoLa) and the Seitz family, and offered to buy out both KW's controlling block and outside shareholders (prompting KW to offer to match APV's bid). APV won support for this deal from the SEN board and the trade unions, arguing that unlike KW, APV would not rationalise the firm. In coalition with the remaining minority shareholders, APV then obstructed KW's attempts at controlling SEN, for instance by voting against supervisory board appointees; while KW sought an EGM to sack the 10 out of 12 supervisory board members hostile to it. In the end, APV abandoned its control bid and sold out to KW, making a $14.6 \%$ return over one year on the stake sale. Controlling $90 \%$ of votes, $\mathrm{KW}$ then forced a profit transfer and control agreement on SEN, and offered to buy-out minorities at a $12.9 \%$ discount to the price it paid APV, and an $18 \%$ discount to the market price.

\section{Wünsche}

The control contest began when the family coalition, which in total controlled over two-thirds of votes, broke down. After being dismissed from the management board by his brother Kai Wünsche (the CEO and 44\% blockholder) for alleged insider dealing, W-J Wünsche turned vociferous critic of the management and supervisory boards, lobbying to oust the supervisory board for failing to carry out its control duties. Wünsche eventually sold his $26 \%$ blocking minority stake to two outsiders at a $24 \%$ discount to the market price. The new blockholders, one of whom wanted the company broken up, pooled their votes and - even though they were still bound by Wünsche's original pooling agreement with his brother-put pressure on the CEO to eventually step down. Once Kai Wünsche had agreed to resign as CEO to move into the supervisory board, the two outside blockholders sold their stakes to a new financial investor group, who also acquired a $4.9 \%$ from WestLB to form a blocking minority stake of $25.1 \%$. The new CEO acquired a $10 \%$ stake on assuming office, while Kai Wünsche reduced his then $42 \%$ stake to $30 \%$. When the CEO change was first rumoured, the share price rose $28 \%$ in one day. The new CEO proceeded to sell off a string of peripheral businesses with a view to refocusing the company. 


\section{References}

Allen, F. and D. Gale (1994), “A welfare comparison of the German and US financial systems", LSE Financial Markets Group Discussion Paper no. 191.

Barclay, M.J. and C.G. Holderness (1989), "Private benefits from control of public corporations", Journal of Financial Economics 25(2), 371-395.

Barclay, M. and C.G. Holderness (1991), "Negotiated block trades and corporate control", Journal of Finance 46(3), 861-878.

Barclay, M. and C.G. Holderness (1992), "The law and large-block trades", Journal of Law and Economics 35, 265-294.

Baums, T. and C. Fraune (1994), "Institutionelle Anleger und Publikumsgesellschaft", Die Aktiengesellschaft 3, 106-124.

Bergström, C, P. Högfeldt and K. Högholm (1994), "Tests of a new theory of strategic blocking by large shareholders and arbitrageurs in takeovers", mimeo, Stockholm School of Economics.

Berle, A. and G. Means (1932), The modern corporation and private property, New York: Macmillan.

Bethel, J.E, J.P. Liebeskind and T. Opler (1998), "Block share purchases and corporate performance", Journal of Finance 53(2), 605-634.

Bolton, P. and E.-L. von Thadden (1998), "Blocks, liquidity and corporate control”, Journal of Finance 53(1), 1-26.

Bulow, J., M. Huang and P. Klemperer (1996), "Toeholds and takeovers”, mimeo, Nuffield College, Oxford.

Burkart, M. (1996), "Economics of takeover regulation”, mimeo, Stockholm School of Economics.

Butz, D.A. (1994), "How do large minority shareholders wield control?", Managerial and Decision Economics, 15(4), 291-298.

Carney, W.J. (1997), "Large bank stockholders in Germany: Saviours or substitutes?", Journal of Applied Corporate Finance 9(4), 74-81.

Choi, D. (1991), "Toehold acquisitions, shareholder wealth and the market for corporate control", Journal of Financial and Quantitative Analysis 26, 391-407.

Comment, R. and G.W. Schwert (1997), "Hostility in takeovers: In the eyes of the beholder?", mimeo, University of Rochester.

Corbett, J. and T.J. Jenkinson (1996), "The financing of industry, 1970-1989: an international comparison", Journal of the Japanese and International Economies, 10(1), 71-96.

Denis, D.J. and J.M. Serrano (1996), "Active investors and management turnover following unsuccessful control contests”, Journal of Financial Economics 40(2), 239-266.

Dewatripont, M. (1993), “The 'leading shareholder' strategy, takeover contests and stock price dynamics”, European Economic Review 37, 983-1004. 
Edwards, J.S.S. and K. Fischer (1994), Banks, finance and investment in West Germany since 1970, Cambridge: Cambridge University Press.

Frankel, A. and D. Palmer (1996), "The management of financial risks at German non-financial firms: the case of Metallgesellschaft", mimeo, Board of Governors of the Federal Reserve System.

Franks, J. and C.P. Mayer (1990), "Capital markets and corporate control: a study of France, Germany and the UK”, Economic Policy 10, 191-231.

Franks, J. and C.P. Mayer (1995), "Ownership, control and the performance of German corporations", mimeo, Oxford University.

Grossman, S. and O. Hart (1980), "Take-over bids, the free-rider problem and the theory of the corporation", Bell Journal of Economics, 42-64.

Grundfest, J.A. (1990), “Subordination of American capital”, Journal of Financial Economics 27(1), $89-114$.

Holderness, C.G. and D.P. Sheehan (1985), "Raiders or saviors? The evidence on six controversial investors", Journal of Financial Economics 14(4), 555-579.

Holmström, B. and J. Tirole (1993), "Market liquidity and performance monitoring", Journal of Political Economy 101(4), 678-709.

Jenkinson, T.J. and C.P. Mayer (1994), Hostile takeovers - Defence, attack and corporate governance, London: McGraw-Hill.

Jensen, M. (1993), "The modern industrial revolution, exit, and the failure of internal control systems", Journal of Finance 48(3), 831-880.

Kaplan, S. (1994), "Top executives, turnover, and firm performance in Germany”, Journal of Law and Economics 10(1), 142-159.

Mikkelson, W. and R. Ruback (1985), "An empirical analysis of the interfirm equity investment process", Journal of Financial Economics 14, 523-553.

Mørck, R. A. Shleifer and R.W. Vishny (1989), “Alternative mechanisms for corporate control”, American Economic Review 79(4), 842-852.

Nicodano, G. and A. Sembenelli (1996), "Block transaction premia and partial private benefits", mimeo, Turin University.

Rajan, R.G. and L. Zingales (1995), "What do we know about capital structure? Some evidence from international data", Journal of Finance 50(5), 1421-1460.

Roe, M.J. (1990), "Political and Legal Restraints on Ownership and Control of Public Companies", Journal of Financial Economics 27(1), 7-14.

Shleifer, A. and R. Vishny (1986), "Large shareholders and corporate control", Journal of Political Economy 94(3), 461-488.

Smith, M.P. (1996), "Shareholder activism by institutional investors: Evidence for CalPERS", Journal of Finance 51(1), 227-252. 
Spencer, C., A. Akhigbe and J. Madura (1998), "Impact of partial control on policies enacted by partial targets", Journal of Banking and Finance 22, 425-445.

Wenger, E. and C. Kaserer (1996), "The German system of corporate governance-a model that should not be imitated", mimeo, University of Würzburg.

Wenger, E. and R. Hecker (1995), "Übernahme- und Abfindungsregeln am deutschen AktienmarktEine kritische Bestandsaufnahme im internationalen Vergleich”, ifo Studien 41, 51-87.

Wruck, K.H. (1989), "Equity ownership concentration and firm value: Evidence from private equity financings", Journal of Financial Economics 23, 3-28.

Zwiebel, J. (1995), "Block investment and partial benefits of corporate control”, Review of Economic Studies 62(2), 161- 


\begin{tabular}{|c|c|c|}
\hline Panel A: Majority control & $\begin{array}{l}\text { number } \\
\text { of firms }\end{array}$ & $\begin{array}{r}\% \text { of } \\
\text { sample }\end{array}$ \\
\hline single or formally pooled $90 \%+$ block & 129 & $23.1 \%$ \\
\hline $\begin{array}{l}\text { single or formally pooled super-majority }(75 \%+) \text { owner } \\
\text { of which have ... } \\
1 \text { additional disclosed blockholder } \\
2 \text { or more additional blockholders }\end{array}$ & $\begin{array}{r}11 \\
2\end{array}$ & $18.4 \%$ \\
\hline $\begin{array}{l}\text { single or formally pooled majority }(50 \%+) \text { owner } \\
\text { of which have ... } \\
1 \text { additional disclosed blockholder } \\
2 \text { or more additional blockholders }\end{array}$ & $\begin{array}{l}59 \\
22\end{array}$ & $30.5 \%$ \\
\hline Total with majority control & 402 & $72.0 \%$ \\
\hline Panel B: Blocking-minority control & $\begin{array}{l}\text { number } \\
\text { of firms }\end{array}$ & $\begin{array}{r}\% \text { of } \\
\text { sample }\end{array}$ \\
\hline $\begin{array}{l}\text { one blocking minority (25\%+) block } \\
\text { of which have ... } \\
1 \text { additional disclosed blockholder } \\
2 \text { or more additional blockholders }\end{array}$ & $\begin{array}{r}8 \\
12\end{array}$ & $8.4 \%$ \\
\hline $\begin{array}{l}\text { two blocking minority }(25 \%+) \text { blocks } \\
\text { of which have... } \\
1 \text { additional disclosed blockholder } \\
2 \text { or more additional blockholders }\end{array}$ & $\begin{array}{l}8 \\
3\end{array}$ & $5.0 \%$ \\
\hline $\begin{array}{l}\text { three blocking minority }(25 \%+) \text { blocks } \\
\text { of which have... } \\
1 \text { additional disclosed blockholder }\end{array}$ & 11 & $2.0 \%$ \\
\hline Total with blocking-minority control & 86 & $15.4 \%$ \\
\hline Panel C: No blocking-minority control & $\begin{array}{l}\text { number } \\
\text { of firms }\end{array}$ & $\begin{array}{r}\% \text { of } \\
\text { sample }\end{array}$ \\
\hline $\begin{array}{l}\text { one or more non-blocking blocks (<25\%) } \\
\text { of which have... } \\
1 \text { block } \\
2 \text { blocks } \\
3 \text { blocks } \\
4 \text { or more blocks }\end{array}$ & $\begin{array}{r}12 \\
9 \\
5 \\
11\end{array}$ & $6.6 \%$ \\
\hline widely held (no blocks disclosed at all) & 18 & $3.2 \%$ \\
\hline Total with no blocking minority control & 55 & $9.8 \%$ \\
\hline ownership information not available & 15 & $2.7 \%$ \\
\hline Grand total & 558 & $100.0 \%$ \\
\hline
\end{tabular}

Source: Own calculations based on "Saling 1992", Hoppenstedt's stock market yearbook. Notes: The law requires disclosure of blocks of more than $25 \%$ and more than $50 \%$. Frequently, smaller blocks are also disclosed (as in Panel C). Non-disclosure need not imply non-existence. 
Table 2: Defensive share structures of German stock-exchange listed companies, 1991.

\begin{tabular}{|c|c|c|c|c|}
\hline number of firms with ... & $\begin{array}{r}\text { only non- } \\
\text { voting } \\
\text { shares } \\
\text { listed }\end{array}$ & $\begin{array}{c}\text { cap on } \\
\text { voting } \\
\text { rights }\end{array}$ & $\begin{array}{r}\text { limited } \\
\text { share } \\
\text { transfer- } \\
\text { ability }\end{array}$ & $\begin{array}{r}\text { departures } \\
\text { from one- } \\
\text { share-one- } \\
\text { vote }\end{array}$ \\
\hline \multicolumn{5}{|l|}{ Panel A: Majority control (402 firms) } \\
\hline single or formally pooled $90 \%+$ block & 22 & & 3 & 4 \\
\hline single or formally pooled super-majority $(75 \%+)$ owner & 6 & & 6 & 4 \\
\hline single or formally pooled majority $(50 \%+)$ owner & 5 & & 5 & 11 \\
\hline $\begin{array}{l}\text { Total } \\
\text { (\% of all firms with majority owner) }\end{array}$ & $\begin{array}{r}33 \\
8.2 \%\end{array}$ & & $\begin{array}{r}14 \\
3.5 \%\end{array}$ & $\begin{array}{r}19 \\
4.7 \%\end{array}$ \\
\hline \multicolumn{5}{|l|}{ Panel B: Blocking-minority control (86 firms) } \\
\hline one blocking minority $(25 \%+)$ block & & 2 & 3 & 3 \\
\hline two blocking minority $(25 \%+)$ blocks & 1 & 1 & 3 & 4 \\
\hline three blocking minority $(25 \%+)$ blocks & 1 & & & \\
\hline $\begin{array}{l}\text { Total } \\
\text { (\% of all firms with a blocking-minority) }\end{array}$ & $\begin{array}{r}\mathbf{2} \\
2.3 \%\end{array}$ & $\begin{array}{r}3 \\
3.5 \%\end{array}$ & $\begin{array}{r}6 \\
7.0 \%\end{array}$ & $\begin{array}{r}7 \\
8.1 \%\end{array}$ \\
\hline \multicolumn{5}{|l|}{ Panel C: No blocking-minority control (55 firms) } \\
\hline one or more non-blocking blocks (<25\%) & & 10 & 3 & 1 \\
\hline widely held (no blocks disclosed at all) & & 7 & & 2 \\
\hline $\begin{array}{l}\text { Total } \\
\text { (\% of all firms with no blocking minority) }\end{array}$ & $\begin{array}{r}0 \\
0 \%\end{array}$ & $\begin{array}{r}17 \\
30.9 \%\end{array}$ & $\begin{array}{r}3 \\
5.5 \%\end{array}$ & $\begin{array}{r}3 \\
5.5 \%\end{array}$ \\
\hline Ownership information not available (15 firms) & 2 & 1 & 2 & 3 \\
\hline $\begin{array}{l}\text { Grand total } \\
\text { (\% of all German listed companies) }\end{array}$ & $\begin{array}{r}37 \\
6.6 \% \\
\end{array}$ & $\begin{array}{r}21 \\
3.8 \% \\
\end{array}$ & $\begin{array}{r}25 \\
4.5 \% \\
\end{array}$ & $\begin{array}{r}32 \\
5.7 \% \\
\end{array}$ \\
\hline
\end{tabular}

Source: Own calculations based on "Saling 1992", Hoppenstedt's stock market yearbook 
Table 3: Potential Targets for Hostile Stake-Builders

\begin{tabular}{|c|c|c|c|c|c|c|}
\hline \multirow[b]{2}{*}{$\begin{array}{l}\text { firms which could become the target of hostile stake-building } \\
\text { (in order of increasing difficulty) }\end{array}$} & \multirow{2}{*}{$\begin{array}{l}\text { Total } \\
\text { number } \\
\text { of firms }\end{array}$} & \multicolumn{4}{|c|}{ Impediments to hostile stake-building } & \multirow{2}{*}{$\begin{array}{r}\text { Number of } \\
\text { firms } \\
\text { without } \\
\text { takeover } \\
\text { defences }\end{array}$} \\
\hline & & $\begin{array}{r}\text { only non- } \\
\text { voting } \\
\text { shares } \\
\text { listed }\end{array}$ & $\begin{array}{r}\text { cap on } \\
\text { voting rights }\end{array}$ & $\begin{array}{r}\text { limited } \\
\text { share } \\
\text { transferability }\end{array}$ & $\begin{array}{r}\text { departures } \\
\text { from } \\
\text { one-share- } \\
\text { one-vote }\end{array}$ & \\
\hline $\begin{array}{l}\text { Strategy 1: } \\
\text { could (potentially) take over in the open market (free float > 50\%) } \\
\text { widely held firms; } \\
\text { firms with } 1 \text { blocking-minority stake and a free float of } 50 \%+; \\
\text { firms with } 1 \text { or more non-blocking stakes and free float of } 50 \%+\end{array}$ & 79 & 0 & 17 & 2 & 1 & 59 \\
\hline $\begin{array}{l}\text { Strategy 2: } \\
\text { in addition, could (potentially) take over if bought out one or more or } \\
\text { all existing non-blocking stakes } \\
\quad \text { the remaining firms with } 1 \text { or more non-blocking stakes }\end{array}$ & 7 & 0 & 1 & 1 & 0 & 5 \\
\hline $\begin{array}{l}\text { Strategy 3: } \\
\text { in addition, could (potentially) take over if bought out one existing } \\
\text { blocking-minority stake plus open-market purchases } \\
\quad \text { firms with } 1 \text { blocking-minority stakes and a free float of } 25 \%+\text {; } \\
\quad \text { firms with } 2 \text { blocking-minority stakes and free float of } 25 \%+\end{array}$ & 30 & 1 & 1 & 3 & 0 & 25 \\
\hline $\begin{array}{l}\text { Strategy 4: } \\
\text { in addition, could (potentially) take over if bought out two existing } \\
\text { blocking-minority stakes } \\
\text { firms with } 2 \text { blocking-minority stakes and a free float of less than } 25 \% \text {; } \\
\text { firms with } 3 \text { blocking-minority stakes and free float of less than } 25 \%\end{array}$ & 25 & 1 & 1 & 2 & 0 & 21 \\
\hline $\begin{array}{l}\text { Grand total } \\
\text { (\% of all German listed companies) }\end{array}$ & $\begin{array}{r}141 \\
25.3 \%\end{array}$ & & & & & $\begin{array}{r}110 \\
19.7 \%\end{array}$ \\
\hline
\end{tabular}

Notes:This table is based on an analysis of the companies which appear in Panels B and C in Table 1. In the final column, the number of potential takeover targets was reduced if and only if the existing limits to share transferability or multiple voting rights applied to a sufficiently large number of votes to effectively rule out hostile stake-building. 
Table 4: Stakebuilders and targets

\begin{tabular}{|c|c|c|c|c|c|c|}
\hline Target company & $\begin{array}{l}\text { Base } \\
\text { year }^{a}\end{array}$ & Industry & Stakebuilder & $\begin{array}{l}\text { Country } \\
\text { of origin }\end{array}$ & Industry & $\begin{array}{l}\text { Industrial } \\
\text { relationship } \\
\text { with target }\end{array}$ \\
\hline $\begin{array}{l}\text { AMB Aachener und } \\
\text { Münchener Beteiligungen }\end{array}$ & 1991 & Insurance & AGF & France & Insurance & Horizontal \\
\hline Asko & 1992 & Retailing & Metro & Switzerland & Retailing & Horizontal \\
\hline Axel Springer Verlag & 1987 & Media/publishing & $\begin{array}{l}\text { Kirch group vs. Burda } \\
\text { brothers vs. Springer } \\
\text { heirs }\end{array}$ & $\begin{array}{l}\text { Germany/ } \\
\text { Germany/ } \\
\text { Germany }\end{array}$ & $\begin{array}{l}\text { Media/ } \\
\text { Publishing }\end{array}$ & Horizontal \\
\hline $\begin{array}{l}\text { Bibliographisches Institut } \\
\text { \& F.A. Brockhaus (BIFAB) }\end{array}$ & 1988 & Publishing & $\begin{array}{l}\text { Maxwell } \\
\text { Communication Corp. }\end{array}$ & $\begin{array}{l}\text { United } \\
\text { Kingdom }\end{array}$ & $\begin{array}{l}\text { Media/ } \\
\text { Publishing }\end{array}$ & Horizontal \\
\hline Boge & 1988 & Car parts & Sogefi & Italy & Car parts & Horizontal \\
\hline Bopp \& Reuther & 1989 & $\begin{array}{l}\text { Process } \\
\text { engineering }\end{array}$ & IWKA & Germany & $\begin{array}{l}\text { Process } \\
\text { engineering }\end{array}$ & Horizontal \\
\hline Buderus & 1994 & $\begin{array}{l}\text { Heating systems/ } \\
\text { Metal products }\end{array}$ & Bilfinger \& Berger & Germany & Construction & Vertical \\
\hline Continental & 1989 & Tires & Pirelli & Italy & Tires & Horizontal \\
\hline $\begin{array}{l}\text { Deutsche Beamten- } \\
\text { Versicherung (DBV) }\end{array}$ & 1993 & Insurance & $\begin{array}{l}\text { Commerzbank/ } \\
\text { Winterthur }\end{array}$ & $\begin{array}{l}\text { Germany/ } \\
\text { Switzerland }\end{array}$ & $\begin{array}{l}\text { Bank/ } \\
\text { Insurance }\end{array}$ & Horizontal \\
\hline $\begin{array}{l}\text { Dyckerhoff und Widmann } \\
\text { AG (Dywidag) }\end{array}$ & 1988 & Construction & Walter Group & Germany & Construction & Horizontal \\
\hline Feldmühle Nobel & 1988 & Conglomerate & Veba vs. Stora vs. SCA & $\begin{array}{l}\text { Germany/ } \\
\text { Sweden/ } \\
\text { Sweden }\end{array}$ & $\begin{array}{l}\text { Conglomerate/ } \\
\text { Pulp \& paper/ } \\
\text { Pulp \& paper }\end{array}$ & - \\
\hline Th. Goldschmidt & 1991 & $\begin{array}{l}\text { Metallurgy/ } \\
\text { industrial } \\
\text { chemicals }\end{array}$ & Viag vs. Veba/Rütgers & Germany/ & $\begin{array}{l}\text { Conglomerate/ } \\
\text { Conglomerate }\end{array}$ & - \\
\hline Hoesch & 1991 & Steel & Krupp & Germany & Steel & Horizontal \\
\hline Philipp Holzmann & 1989 & Construction & Hochtief & Germany & Construction & Horizontal \\
\hline Kolbenschmidt & 1994 & Car parts & $\mathrm{T} \& \mathrm{~N}$ plc & $\begin{array}{l}\text { United } \\
\text { Kingdom }\end{array}$ & Car parts & Horizontal \\
\hline Seitz-Enzinger-Noll (SEN) & 1988 & $\begin{array}{l}\text { Process } \\
\text { engineering }\end{array}$ & $\begin{array}{l}\text { Klöckner Werke vs. } \\
\text { APV }\end{array}$ & $\begin{array}{l}\text { Germany/ } \\
\text { United } \\
\text { Kingdom }\end{array}$ & Machine tools & Vertical \\
\hline Wünsche & 1992 & Conglomerate & WCM and Diekell & $\begin{array}{l}\text { Germany/ } \\
\text { Germany }\end{array}$ & $\begin{array}{l}\text { Conglomerate/ } \\
\text { Individual }\end{array}$ & - \\
\hline
\end{tabular}

Notes: (a) base year is defined as the year in which the control contest began 
Table 5: Target company ownership structure, performance, and takeover defences

\begin{tabular}{|c|c|c|c|c|c|c|c|c|c|}
\hline \multirow{3}{*}{ Target company } & \multirow[t]{3}{*}{ Shareholder structure } & \multicolumn{5}{|c|}{ Performance prior to stakebuilding } & \multicolumn{3}{|c|}{ Defences $^{\mathrm{a}}$} \\
\hline & & Sales $^{\mathrm{D}}$ & $\begin{array}{r}\text { Sales } \\
\text { growth }^{\mathrm{C}}\end{array}$ & $\begin{array}{l}\text { Earnings } \\
\text { growth }^{c}\end{array}$ & $\begin{array}{r}\text { Return } \\
\text { on } \\
\text { equity }^{\mathrm{b}}\end{array}$ & $\begin{array}{r}\text { Return } \\
\text { on } \\
\text { sales }^{\text {b }}\end{array}$ & $\begin{array}{c}\text { Cap on } \\
\text { voting } \\
\text { rights }\end{array}$ & $\begin{array}{l}\text { Limited } \\
\text { share } \\
\text { transfer- }\end{array}$ & $\begin{array}{l}\text { Departure } \\
\text { from one- } \\
\text { share-one- }\end{array}$ \\
\hline & & DM million & $\%$ & $\%$ & $\%$ & & & ability & vote \\
\hline AMB & $\begin{array}{l}\text { Fragmented } \\
\text { (no blocking minorities, several small stakes) }\end{array}$ & n.a & n.a. & 4.8 & 5.4 & n.a. & & Yes & \\
\hline Asko & $\begin{array}{l}\text { Fragmented } \\
\text { (no blocking minorities, several small stakes) }\end{array}$ & 13,188 & 20.1 & -29.6 & 3.3 & 0.1 & $5 \%$ & & \\
\hline Axel Springer Verlag & $\begin{array}{l}\text { Fragmented } \\
\text { (one blocking-minority stake, several smaller stakes) }\end{array}$ & 2,220 & 28.4 & 218.8 & 19.1 & 2.6 & & Yes & \\
\hline BIFAB & $\begin{array}{l}\text { Fragmented } \\
\text { (two blocking-minority stakes, one smaller stake) }\end{array}$ & 44 & 8.1 & 51.8 & n.a. & -0.7 & & & \\
\hline Boge & $\begin{array}{l}\text { Widely-held } \\
\text { (two non-blocking stakes) }\end{array}$ & 537 & 8.8 & 25.4 & 7.3 & 1.0 & & & \\
\hline Bopp \& Reuther & $\begin{array}{l}\text { Privately-held } \\
\text { (one outside blocking minority, several family } \\
\text { shareholders, all bound by pooling contract) }\end{array}$ & 185 & -10.8 & $\begin{array}{r}\text { move into } \\
\text { losses }\end{array}$ & n.a. & -5.1 & & & \\
\hline Buderus & $\begin{array}{l}\text { Fragmented } \\
\text { (one blocking-minority stake, several smaller stakes) }\end{array}$ & 2,696 & 3.9 & 11.4 & 16.2 & 2.5 & & & \\
\hline Continental & $\begin{array}{l}\text { Widely-held } \\
\text { (at least two non-blocking stakes) }\end{array}$ & 6,588 & 21.2 & 26.2 & 16.0 & 2.6 & $5 \%$ & & \\
\hline DBV & $\begin{array}{l}\text { Fragmented } \\
\text { (two blocking-minority stakes) }\end{array}$ & 2,199 & 12.6 & 35.8 & 4.7 & 1.7 & & Yes & \\
\hline Dywidag & $\begin{array}{l}\text { Fragmented } \\
\text { (no blocking minorities, several small stakes) }\end{array}$ & 1,459 & 9.2 & -25.9 & 2.7 & 0.4 & & & \\
\hline Feldmühle Nobel & $\begin{array}{l}\text { Fragmented } \\
\text { (no blocking minorities) }\end{array}$ & 8,846 & -3.0 & -4.7 & 10.2 & 2.3 & $5 \%{ }^{e}$ & & \\
\hline Th. Goldschmidt & $\begin{array}{l}\text { Fragmented } \\
\text { (one blocking-minority stake, several smaller stakes) }\end{array}$ & 1,197 & 7.2 & 16.0 & 22.0 & 4.1 & & & Yes $^{d}$ \\
\hline Hoesch & $\begin{array}{l}\text { Widely-held } \\
\text { (at least one non-blocking stake) }\end{array}$ & 10,426 & 8.7 & 29.7 & 5.3 & 0.9 & $15 \%$ & & \\
\hline Philipp Holzmann & $\begin{array}{l}\text { Widely-held } \\
\text { (one disclosed non-blocking stake) }\end{array}$ & 3,937 & 32.3 & 142.7 & 12.9 & 1.2 & & & \\
\hline Kolbenschmidt & $\begin{array}{l}\text { Fragmented } \\
\text { (one blocking-minority stake, several smaller stakes) }\end{array}$ & 1,449 & -3.9 & $\begin{array}{r}\text { move into } \\
\text { losses }\end{array}$ & n.a. & -3.8 & & & \\
\hline SEN & $\begin{array}{l}\text { Majority-controlled } \\
\text { (one } 50.01 \% \text { stake, one blocking-minority stake) }\end{array}$ & 378 & -7.3 & $\begin{array}{r}\text { move into } \\
\text { losses }\end{array}$ & n.a. & -0.3 & & & \\
\hline Wünsche & $\begin{array}{l}\text { Majority-controlled } \\
\text { (two blocking-minority stakes with pooling contract) }\end{array}$ & 1,833 & 6.6 & 29.5 & 21.2 & 1.5 & & & \\
\hline
\end{tabular}

Source: accounting data comes from Hoppenstedt Bilanzdatenbank and various issues of the Saling stock market yearbook.

Notes: (a) none of the target firms we analyse have only non-voting shares listed (b) Measured as the average in the base year and the previous 3 years; (c) Measured as the average growth rate in the base year and the previous 2 years (d) $1.3 \%$ of shares have $11.6 \%$ of votes (e) adopted in response to stake-building rumours 
Table 6: Stake-building strategy

\begin{tabular}{lccc}
\hline Target $\quad$ Source of stake & Acting in $\begin{array}{c}\text { Bank } \\
\text { stake }\end{array}$ & $\begin{array}{c}\text { Bank } \\
\text { assists } \\
\text { stake- } \\
\text { builder }\end{array}$ \\
\hline
\end{tabular}

AMB

AGF bought $1.8 \%$ block from Skandia AB (with whom they acted in concert) and boosted this via open market purchases

Asko

Metro and its house bank WestLB bought $10 \%$ each from Asko (which Asko owned via a subsidiary) to cement a joint venture; however, Metro then bought further shares in the open market

Axel Springer Kirch bought $10 \%$ at the IPO; claimed also to have option on $16 \%$, Verlag source unclear; Burda brothers bought $24.9 \%$ stake from Axel Springer (the deceased founder)

BIFAB Langenscheidt bought initial stake from Meyer family in response to Maxwell's targeted bid

Boge

Open market

Bopp \& Reuther IWKA bought stake from a group of family shareholders, despite pooling agreement

Buderus Unknown, but possibly at time of IPO

Continental Open market

DBV Commerzbank took a stake at the IPO, ostensibly to protect DBV from takeover threats; bought a further stake later to gain majority control

Dywidag

Hostile stakebuilder Walter acquired total of $38 \%$ from the founding family, Siemens AG and its house bank; "white knight" Advanta bought Holzmann's pivotal $24.9 \%$ stake; Holzmann's intentions were to prevent Walter from gaining control by selling stake to white knight-who sold stake on to Walter

Feldmühle Nobel Stora bought out the two nephews of former owner and their coalition of 5 others $(40 \%$, originally secretly assembled) once the coalition failed to win proxy contest due to house-bank supporting incumbent management

Th. Goldschmidt Veba: $20 \%$ from Metallgesellschaft, increased to $25+\%$ from family shareholders; origin of VIAG's rival $20 \%$ unknown; the two new blockholders emerged when there were rifts in the family shareholder coalition and rumours of a rift between management and family shareholders

Hoesch Open market purchases

Holzmann Hochtief bought (options on) stakes from Advanta $\mathrm{GmbH}(10 \%)$ and Commerzbank (4.9\%), its house bank

Kolbenschmidt T\&N bought stakes from Metallgesellschaft (47\%) who were in liquidity crisis; Magna International Canada (2.5\%); and other institutional investors $(3 \%)$

SEN $\quad$ APV offered options on $40 \%$ holding by SEN minority shareholders (stake held by Badische Kommunale Landesbank) to foil forced merger of SEN with KW's subsidiary (KW had bid for the $40 \%$ block); APV tender for remainder at DM175

Wünsche Possibly to end a long-standing feud with his brother, W-J Wünsche sold $25 \%+1$ share stake (of which $6 \%$ were parked with a bank) to WCM and Dieckell, who pooled; this sale was welcomed by brother Kai Wünsche, the CEO of Wünsche. The stake was allegedly sold at a $25 \%$ discount to market price 
Table 7: Defensive actions

Defensive actions

\begin{tabular}{|c|c|c|c|c|c|c|}
\hline Target & $\begin{array}{c}\text { Defensive } \\
\text { alliances }\end{array}$ & $\begin{array}{c}\text { Bank } \\
\text { assists } \\
\text { target }\end{array}$ & $\begin{array}{l}\text { White } \\
\text { knight }\end{array}$ & $\begin{array}{c}\text { Deny } \\
\text { supervisory } \\
\text { board seat }\end{array}$ & $\begin{array}{c}\text { Caps on total } \\
\text { votes per } \\
\text { block }\end{array}$ & $\begin{array}{c}\text { Limited } \\
\text { transferability } \\
\text { of stock }\end{array}$ \\
\hline AMB & $\checkmark$ & & & & & $\checkmark$ \\
\hline Asko & & & & & $\checkmark$ & \\
\hline $\begin{array}{l}\text { Axel Springer } \\
\text { Verlag }\end{array}$ & $\checkmark$ & & & $\checkmark$ & & $\checkmark$ \\
\hline BIFAB & $\checkmark$ & & $\checkmark$ & & & \\
\hline Boge & $\checkmark$ & $\checkmark$ & $\checkmark$ & & & \\
\hline Bopp \& Reuther & $\checkmark$ & & $\checkmark$ & & & \\
\hline \multicolumn{7}{|l|}{ Buderus } \\
\hline Continental & $\checkmark$ & $\checkmark$ & & & $\checkmark$ & \\
\hline \multicolumn{7}{|l|}{ DBV } \\
\hline Dywidag & $\checkmark$ & & $\checkmark$ & $\checkmark$ & & $\checkmark$ \\
\hline Feldmühle Nobel & $\checkmark$ & $\checkmark$ & & & $\checkmark$ & \\
\hline Th. Goldschmidt & $\checkmark$ & & & $\checkmark$ & & \\
\hline Hoesch & $\checkmark$ & & & & $\checkmark$ & \\
\hline \multicolumn{7}{|l|}{ Holzmann } \\
\hline Kolbenschmidt & $\checkmark$ & & $\checkmark$ & & & \\
\hline SEN & $\checkmark$ & & $\checkmark$ & $\checkmark$ & & $\checkmark$ \\
\hline Wünsche & & & & & & \\
\hline
\end{tabular}


Table 8: Outcomes

$\begin{array}{lll}\text { Target } & \text { Outcome Summary } & \begin{array}{l}\text { Management Supervisory Tender to } \\ \text { board } \\ \text { changes minorities }\end{array} \\ \text { changes }\end{array}$

\begin{tabular}{|c|c|c|c|c|c|}
\hline AMB & $\begin{array}{l}\text { Co-operation } \\
\text { with stakebuilder }\end{array}$ & $\begin{array}{l}\text { AGF won voting rights on blocking stake after AMB's } \\
\text { supervisory board turned against CEO }\end{array}$ & CEO resigned & & \\
\hline Asko & $\begin{array}{l}\text { Stakebuilder } \\
\text { succeeded }\end{array}$ & $\begin{array}{l}\text { Supervisory board chair ousted. Voting restrictions then } \\
\text { removed and takeover welcomed }\end{array}$ & & $\begin{array}{l}\text { Chairman } \\
\text { removed }\end{array}$ & $x$ \\
\hline $\begin{array}{l}\text { Axel Springer } \\
\text { Verlag }\end{array}$ & $\begin{array}{l}\text { Co-operation } \\
\text { with stakebuilder }\end{array}$ & $\begin{array}{l}\text { Kirch and Burda family initially pooled stakes against the } \\
\text { Springer family. This broke down when part of the Burda } \\
\text { stake was sold to the Springer family, who ultimately co- } \\
\text { operated with Kirch }\end{array}$ & $\begin{array}{l}\text { Multiple CEO } \\
\text { resignations }\end{array}$ & $\begin{array}{l}\text { Bidder initially } \\
\text { denied then } \\
\text { given seat }\end{array}$ & \\
\hline BIFAB & $\begin{array}{l}\text { White knight } \\
\text { found }\end{array}$ & $\begin{array}{l}\text { The stakebuilding prompted the breakdown of a pooling } \\
\text { agreement, with Langenscheidt gaining control and later } \\
\text { taking BIFAB private }\end{array}$ & & & $\begin{array}{l}\text { Yes, at } 10 \% \\
\text { premium }\end{array}$ \\
\hline Boge & $\begin{array}{l}\text { Defensive } \\
\text { coalition sold to } \\
\text { "grey knight" }\end{array}$ & $\begin{array}{l}\text { A defensive coalition successfully formed. The controlling } \\
\text { group sold out to Mannesmann. Sogefi also sold out to } \\
\text { Mannesmann a few months later }\end{array}$ & & & $\begin{array}{l}\text { Yes, initial } \\
\text { offer at } 64 \% \\
\text { discount }\end{array}$ \\
\hline $\begin{array}{l}\text { Bopp \& } \\
\text { Reuther }\end{array}$ & $\begin{array}{l}\text { Stakebuilder } \\
\text { succeeded }\end{array}$ & $\begin{array}{l}\text { IWKA bought } 43 \% \text { stake. Defensive pooling agreement } \\
\text { broke down when Hannover Finanz sided with IWKA, who } \\
\text { then bought remaining stakes }\end{array}$ & $\begin{array}{l}\text { Management } \\
\text { dismissed }\end{array}$ & & $x$ \\
\hline Buderus & $\begin{array}{l}\text { Blocked by } \\
\text { Cartel Office }\end{array}$ & $\begin{array}{l}\text { Stakebuilder bought a } 15 \% \text { stake, tried to increase it to } \\
25 \% \text { but was blocked }\end{array}$ & & $\begin{array}{l}\text { Bidder given } \\
\text { seat }\end{array}$ & \\
\hline Continental & $\begin{array}{l}\text { Thwarted by } \\
\text { court decisions } \\
\text { on voting rights }\end{array}$ & $\begin{array}{l}\text { Pirelli and allies each bought } 5 \% \text { stakes, but were } \\
\text { ultimately defeated by the fall in Continental's share price } \\
\text { and the failure to remove voting restrictions }\end{array}$ & $\begin{array}{l}\text { CEO removed; } \\
\text { management } \\
\text { board split }\end{array}$ & & \\
\hline DBV & $\begin{array}{l}\text { Bank gained } \\
\text { control then sold } \\
\text { majority stake }\end{array}$ & $\begin{array}{l}\text { Commerzbank held a } 25 \% \text { stake, which it undertook not to } \\
\text { increase. The stake was gradually increased to } 50 \% \text { and } \\
\text { then sold on to a Swiss insurer }\end{array}$ & & & $x$ \\
\hline Dywidag & $\begin{array}{l}\text { Stakebuilder } \\
\text { succeeded }\end{array}$ & $\begin{array}{l}\text { Walter constructed a } 40 \% \text { stake in Dywidag with a view to } \\
\text { takeover. Dywidag responded by welcoming "white knight" } \\
\text { Advanta, who then sold on a critical } 25 \% \text { stake to Walter }\end{array}$ & & $\begin{array}{l}\text { Bidder denied } \\
\text { seat (despite } \\
40 \% \text { stake) }\end{array}$ & $x$ \\
\hline $\begin{array}{l}\text { Feldmühle } \\
\text { Nobel }\end{array}$ & $\begin{array}{l}2^{\text {nd }} \text { stakebuilder } \\
\text { gained control }\end{array}$ & $\begin{array}{l}\text { Initial stakebuilding by Veba blocked by voting restrictions. } \\
\text { Flick brothers then built a stake in opposition to Veba. } \\
\text { Stora took control by buying both stakes }\end{array}$ & & & $\begin{array}{l}\text { Yes, at } 15 \% \\
\text { discount }\end{array}$ \\
\hline $\begin{array}{l}\text { Th. } \\
\text { Goldschmidt }\end{array}$ & $\begin{array}{l}\text { Stakebuilder } \\
\text { succeeded }\end{array}$ & $\begin{array}{l}\text { Viag and Veba both bought stakes, which they pooled and } \\
\text { sought board representation. This was denied. Viag then } \\
\text { bought Veba's stake and a stake owned by Allianz to gain } \\
\text { majority control }\end{array}$ & & $\begin{array}{l}\text { No } \\
\text { representation } \\
\text { granted to } \\
\text { stakeholders }\end{array}$ & Not yet \\
\hline Hoesch & $\begin{array}{l}\text { Stakebuilder } \\
\text { succeeded }\end{array}$ & $\begin{array}{l}\text { Krupp built a } 24.9 \% \text { stake and its advisor Credit Suisse } \\
\text { also took a } 20 \% \text { stake. Along with other blockholders a } \\
\text { voting rights restriction was removed. Among Krupp's allies } \\
\text { were its house bank and Hoesch's house bank }\end{array}$ & $\begin{array}{l}\text { Management } \\
\text { board members } \\
\text { suspended }\end{array}$ & & $\begin{array}{l}\text { Yes, share } \\
\text { offer }\end{array}$ \\
\hline Holzmann & $\begin{array}{l}\text { Blocked by } \\
\text { Cartel Office }\end{array}$ & $\begin{array}{l}\text { Hochtief had long held a } 20 \% \text { stake, which it increased by } \\
\text { taking options on stakes held by banks }\end{array}$ & & & \\
\hline Kolbenschmidt & $\begin{array}{l}\text { Blocked by } \\
\text { Cartel Office. } \\
\text { Controlling block } \\
\text { sold to } 2^{\text {nd }} \text { bidder }\end{array}$ & $\begin{array}{l}\text { T\&N built a controlling block, but were prevented from } \\
\text { taking control by the Cartel Office. Pending an appeal, } \\
\text { Commerzbank acquired the block and granted options to } \\
\text { T\&N. Ultimately, Commerzbank placed } 25 \% \text { with } \\
\text { Rheinmetall, who later also acquired the remaining } 25 \%\end{array}$ & & & $x$ \\
\hline SEN & $\begin{array}{l}\text { Stakebuilder } \\
\text { succeeded }\end{array}$ & $\begin{array}{l}\text { Rival stakebuilder opposed controlling shareholder } \\
\text { Klöckner Werke, but ultimately sold its stake to the latter }\end{array}$ & $\begin{array}{l}\text { Management } \\
\text { board opposed } \\
\text { forced merger }\end{array}$ & $\begin{array}{l}\text { Rival bidder } \\
\text { blocked seats } \\
\text { for controlling } \\
\text { shareholder }\end{array}$ & $\begin{array}{l}\text { Yes, at } 18 \% \\
\text { discount }\end{array}$ \\
\hline Wünsche & $\begin{array}{l}\text { Stakebuilders } \\
\text { sold out once } \\
\text { the CEO was } \\
\text { removed }\end{array}$ & $\begin{array}{l}\text { A family feud resulted in one brother being removed from } \\
\text { the management board. He then sold his } 26 \% \text { stake to two } \\
\text { outsiders, who pressured the CEO to resign. Rumours } \\
\text { about the CEO change led to } 28 \% \text { share price rise }\end{array}$ & CEO resigned & & $x$ \\
\hline
\end{tabular}


Table 9: Performance before and after contest

\begin{tabular}{|c|c|c|c|c|c|}
\hline \multirow[b]{2}{*}{ Target company } & \multirow[b]{2}{*}{ Outcome } & \multicolumn{2}{|c|}{ Return on Equity } & \multicolumn{2}{|c|}{ Return on Sales } \\
\hline & & $\begin{array}{c}\text { average of } \\
\text { three years } \\
\text { pre-contest } \\
\%\end{array}$ & $\begin{array}{c}\text { average of } \\
\text { three years } \\
\text { post-contest } \\
\%\end{array}$ & $\begin{array}{c}\text { average of } \\
\text { three years } \\
\text { pre-contest } \\
\%\end{array}$ & $\begin{array}{c}\text { average of } \\
\text { three years } \\
\text { post-contest } \\
\%\end{array}$ \\
\hline AMB & Co-operation & 5.4 & 6.2 & n.a. & n.a. \\
\hline Asko & Control change & 3.3 & 5.5 & 0.1 & 0.5 \\
\hline Axel Springer Verlag & Co-operation & 19.1 & 25.0 & 2.6 & 2.9 \\
\hline BIFAB & Control change & n.a. & 17.8 & -0.7 & 4.4 \\
\hline Boge & Control change & 7.3 & 5.7 & 1.0 & 0.5 \\
\hline Bopp \& Reuther & Control change & n.a. & n.a. & -5.1 & -4.1 \\
\hline Buderus & No change & 16.2 & 21.4 & 2.5 & 3.4 \\
\hline Continental & No change & 16.0 & 10.9 & 2.6 & 1.0 \\
\hline DBV & Control change & 4.7 & 8.0 & 1.7 & 2.5 \\
\hline Dywidag & Control change & 2.7 & 5.0 & 0.4 & 0.4 \\
\hline Feldmühle Nobel & Control change & 10.2 & 13.4 & 2.3 & 2.1 \\
\hline Th. Goldschmidt & Control change & 22.0 & 15.2 & 4.1 & 3.2 \\
\hline Hoesch & Control change & 5.3 & n.a. & 0.9 & -0.6 \\
\hline Philipp Holzmann & No change & 12.9 & 15.1 & 1.2 & 1.0 \\
\hline Kolbenschmidt & Control change & n.a. & 11.9 & -3.8 & 2.1 \\
\hline SEN & Control change & n.a. & 1.6 & -0.3 & 0.0 \\
\hline Wünsche & Control change & 21.2 & 24.0 & 1.5 & 2.1 \\
\hline
\end{tabular}

Source: Hoppenstedt Bilanzdatenbank and various issues of the Saling stock market yearbook. 